\title{
Hajléktalan emberek pszichoaktív szerhasználata
}

\author{
Paksi Borbála - Magi Anna - Gurály Zoltán \\ PAKSI BorbálA: ELTE Neveléstudományi Intézet; Viselkedéskutató Társadalomtudományi és \\ Szolgáltató Kft. - paksi.borbala@viselkedeskutato.hu \\ MAGI ANNA: ELTE Pszichológiai Intézet; ELTE Pszichológiai Doktori Iskola - magi.anna@ppk.elte.hu \\ GURÁlY ZoltáN: Menhely Alapítvány; Február Harmadika Munkacsoport - \\ zoltan.guraly@gmail.com
}

\begin{abstract}
ABSZTRAKT A tanulmány a lakossági vizsgálatokból kimaradó, ugyanakkor a rendelkezésre álló szakirodalmi adatok alapján a pszichoaktív szerek használata szempontjából különösen veszélyeztetett, speciális társadalmi csoportok egyikének, a hajléktalan embereknek a drogfogyasztásával és egyéb pszichoaktív szerhasználatával foglalkozik. Magyarországon 2007 februárjában, a fővárosban készült az első olyan kutatás, amely célzottan vizsgálta a hajléktalan populáció drogérintettségét, droghasználati szokásait. Ezt követően egy évtizeden keresztül nem készült hasonló vizsgálat. A tanulmányban bemutatásra kerülő kutatás - Európában egyedülálló módon - országos reprezentatív mintán készült, a hajléktalan populáció legjobb becslését adó, „Február Harmadika (F3)” kutatássorozat 2017-es adatfelvételéhez kapcsolódva, az általános populációs adatfelvételekben is alkalmazott nemzetközi ajánlásokat megjelenítő ún. modellkérdőív felhasználásával. Az alkalmazott módszertan biztosítja az eredmények kiterjeszthetőségét a magyarországi hajléktalan emberekre, továbbá lehetővé teszi az adatok általános populációs kontextusban való értelmezését, a hajléktalan emberek speciális szerhasználati jellemzőinek azonosítását, valamint az elmúlt 10 év fővárosi tendenciáinak felvázolását. 2007-ben még azt mondhattuk, hogy a drogokkal való kapcsolatba kerülés tekintetében a fővárosi hajléktalan emberek kitettsége átlagosnak tekinthető, csak szerhasználati szokásaik veszélyesebbek, mint általában a lakosságé. A tanulmányban bemutatott kutatási eredmények alapján azonban azt láthatjuk, hogy 10 évvel később a hajléktalan emberek droghasználati kitettsége már többszöröse az általános népességben tapasztalhatónak, s a fogyasztásuk továbbra is fokozottan kockázatos.
\end{abstract}

Kulcsszavak: droghasználat, egyéb pszichoaktív szerhasználat, hajléktalan populáció

\section{Psychoactive substance use by homeless people}

ABSTRACT The study addresses the drug and other psychoactive substance use of one of the special social groups, homeless people, who are excluded from population-based studies but are particularly vulnerable to the use of psychoactive substances based on the available literature. The first research in Hungary targeting the drug involvement and drug use habits of the homeless population was carried out in February 2007 in the capital, Budapest. After that no similar study was conducted for a decade. The research presented in the study is based on - in a unique way in Europe - a nationally representative sample of the "February Third (F3)" research series in 2017, which gives the best estimate of the homeless population. The questions applied to measure substance use were based on the recommendation of European Model Questionnaire for general population surveys. The applied methodology ensures the extensibility of the results to homeless people in Hungary, allows the interpretation of data in the context of the general population, the identification of special substance use characteristics of homeless people, as well as the outlining of the trends of the capital over the previous 10 years. In 2007, we could say that the exposure to drugs of homeless people in the capital could be considered average, only their substance use habits were more dangerous than those of the general population. However, 10 years later 
based on the results presented in the study, even the exposure of homeless people to drug use is several times higher than in the general population, and their use is still at increased risk.

Keywords: drug use, other psychoactive substance use, homeless population

\section{BEVEZETÉS - A TANULMÁNY CÉLJA}

A társadalom szerhasználatának átfogó becslésére szolgáló általános populációs kutatások során kimaradhatnak vagy alulreprezentálttá válhatnak bizonyos rejtőzködő vagy egyéb ok miatt nehezen elérhető társadalmi csoportok. Ezek sok esetben pszichoaktív szerhasználat tekintetében is speciális helyzetü és/vagy nagy kitettségű csoportok. Az egyik ilyen, a lakossági vizsgálatokból kimaradó társadalmi csoport, a hajléktalan populáció.

A hajléktalanság és drogfogyasztás kapcsolatával foglalkozó elemzések egyik típusa a drogfogyasztók lakhatási problémái felől közelíti a droghasználat és a hajléktalanság összefüggését, a másik megközelítés pedig a hajléktalan populáció drogérintettségének feltárására fókuszál. Mindkét megközelítés kihívásokkal teli. A kihívások egy része a hajléktalansággal és/vagy a pszichoaktív szerhasználattal kapcsolatos fogalomhasználathoz, illetve a fogalmak gyakorlati alkalmazásához köthető', de a hajléktalan és a droghasználó populáció rejtekező volta miatt nehézségekbe ütközik a droghasználó vagy a hajléktalan populáció azonosítása, az abból való mintavétel is. Ezek a nehézségek számos, az adatok érvényességével, illetve megbízhatóságával, az eredmények értelmezésével és általánosíthatóságával kapcsolatos problémával terhelik a hajléktalan emberek szerhasználatának megismerését.

A hajléktalan populációban 2000 és 2017 (Paksi - Gurály - Arnold - Schmidt - Breitner 2008, Paksi - Magi 2017) közötti időszakban az Európai Unió országaiban készült kutatások szisztematikus áttekintése alapján azt látjuk, hogy gyakorlatilag nincs olyan vizsgálat, mely országos reprezentatív mintán, célzottan a pszichoaktív szerhasználatra vonatkozó, drogepidemiológiai adatokkal szolgál a hajléktalan populáció szerhasználatáról. A lokális mintán - a hajléktalan populációs bizonyos szegmenseiben, egy-egy kisebb területen - vagy egy-egy szolgáltató klienskörében készült kutatások körében sem tudtunk célzottan drogepidemiológiai adatokkal szolgáló kutatást azonosítatni. A kutatások fogalomhasználata nem egységes a célpopuláció vonatkozásában, sok esetben nem az ETHOS tipológiarendszerrel kompatibilis definíciókat alkalmaznak a hajléktalan populáció meghatározása során. Definíciós problémák azonosíthatók a pszichoaktív szerhasználattal kapcsolatos kérdések vonatkozásában is. A kutatások nem alkalmazzák az addiktológiai kutatások tekintetében megfogalmazott nemzetközi ajánlások (EMCDDA 2002, 2015) módszertani standardjait és fogalomkészletét, így nem

\footnotetext{
1 Az Európai Hajléktalanellátók Egyesülete (FEANTSA) 2005-ben kidolgozott ugyan egy egységes definíciós struktúrát, az ún. ETHOS (European Typology on Homelessness and housing exclusion) tipológiát (Bill - Henk 2006), amely a hajléktalanság különböző megjelenési formái, illetve az egyes hajléktalan élethelyzetek szerint négy kategóriába sorolja a hajléktalanokat: fedélnélküliek (közterületen, éjjeli menedékhelyen élők), lakástalanok (hajléktalanszállón, átmeneti szállón élők), bizonytalan/veszélyeztetett (nincs bérleti jogviszony, kilakoltatási végzés, bántalmazás), illetve elégtelen (ideiglenes építmény, alkalmatlan lakás) lakhatási körülmények között élők. Azonban a hajléktalan populáció különböző szegmensei közötti mozgás, a populáció térbeli és időbeli változékonysága okán a különböző hajléktalan definíciók gyakorlati alkalmazása nem egyszerű feladat (Bényei - Gurály - Győri - Mezei 2000, Dávid - Snijders 2000).
} 
csak a hajléktalan populáción végzett kutatások összehasonlítása, de azok normál populációs kontextusban való értelmezése is rendkívül problematikus.

Magyarországon is a jelen tanulmányunk alapját képező kutatás az első országos reprezentatív mintán készült, célzottan a hajléktalan populáció drogérintettségét, droghasználati szokásait vizsgáló kutatás, ami lehetőséget ad országosan érvényes állítások megfogalmazására a hajléktalan emberek droghasználatával kapcsolatosan. Ezt megelőzően 2007-ben, a fővárosi hajléktalanok körében készült Magyarországon először olyan drogepidemiológiai kutatás, amely a hajléktalanság és droghasználat viszonyát a hajléktalan populáció érintettsége oldaláról közelítette meg (Paksi et al. 2008, Paksi - Arnold - Schmidt - Gurály - Breitner 2010). A kutatás rámutatott, hogy a fóvárosi hajléktalan emberek drogokkal való kapcsolatba kerülésének kockázata ugyan az általános populációéval megegyező, azonban a problémás/kockázatos droghasználatra utaló magatartások tekintetében különösen veszélyeztetettnek tekinthetők. A fövárosban élö, drogokkal már kapcsolatba került hajléktalan emberek körében a marihuána/hasis használat kevésbé jelentett önálló fogyasztási kategóriát, az egyéb drogok elterjedtsége relatíve magasabb, a folyamatos használat kockázata többszöröse az általános populációban tapasztaltnak, azaz a kilépés esélye jóval kisebb, s a hajléktalan droghasználók esetében gyakrabban jelentkeztek a drogfogyasztás okozta következményes károsodások, mint az általános népességhez tartozó drogfogyasztóknál.

A hajléktalan droghasználók relatíve kockázatosabb droghasználó magatartása nem magyarországi sajátosság. Ugyan - mint említettük - a hajléktalanok drogfogyasztásáról a más európai országokból rendelkezésre álló adatok az alkalmazott módszerek heterogenitása miatt igen nehezen összehasonlíthatók, mindazonáltal a különböző országokban az általános populációhoz képest a hajléktalanok droghasználatának sajátosságai tekintetében megmutatkozó tendenciák meglehetősen egybehangzóak (Paksi et al. 2008).

Tanulmányunk az első, a hajléktalan emberek országos reprezentatív mintáján készült célzott drogepidemiológiai vizsgálat eredményeit mutatja be, a hajléktalanság és droghasználat viszonyát a hajléktalan populáció érintettsége oldaláról közelítve. A kutatás célja a magyarországi hajléktalan populáció drog- és egyéb pszichoaktív szerhasználatának vizsgálata, ezen belül a következő célokat fogalmaztuk meg:

i. A hajléktalan populáció drogérintettségének becslése.

ii. A populációban jellemző fogyasztási szokások (szerhasználati mintázatok, együttfogyasztások, veszélyeztető fogyasztási típusok) leírása.

iii. A hajléktalan droghasználók társadalmi jellemzői (alapvető demográfiai jellemzők, a hajléktalan társadalom egyes alcsoportjaiba való tartozás stb.) mentén jelentkező mintázatok feltárása.

iv. A hajléktalan populáció egyéb pszichoaktív szerhasználata elterjedtségének (alkoholfogyasztás, dohányzás, visszaélésszerű gyógyszerhasználat, inhaláns-használat) vizsgálata.

v. A hajléktalan populáció drogérintettségében, fogyasztási szokásaiban és a kockázati tényezőkben mutatkozó tendenciák becslése.

vi. A hajléktalan populáció szerhasználati szokásaiban - az általános népességre vonatkozó adatok kontextusában - megjelenő sajátosságok azonosítása.

Tanulmányunkban - a felhasznált adatok módszertani hátterének ismertetését követöen - az eredmények bemutatása során a célok szerinti struktúrát követjük. 


\section{FELHASZNÁLT ADATOK, A KUTATÁS MÓDSZERE}

A prevalenciabecslés, illetve az adatok időbeli és más populációk kontextusában való értelmezése miatt az adatfelvétel során alkalmazott metodika megválasztását egyrészt a reprezentativitást biztosító mintavétel megvalósítására való törekvés, valamint a drogepidemiológiai kutatások során általában alkalmazott nemzetközi standardok és hazai hagyományok érvényesítése határozta meg.

A kutatás adatfelvétele - az egy évtizeddel korábbi, 2007-es kutatásunk során kimunkált (Paksi et al. 2008, 2010) módszertanhoz hasonlóan - omnibusz jelleggel a hajléktalan populáció legjobb becslését adó, nagy hazai hagyományokkal rendelkezo, ún. „Február Harmadika” (F3) kutatássorozat ${ }^{2}$ 2017. évi adatfelvételéhez kapcsolódott (F3 Drog- és egyéb pszichoaktívszer-használat kutatás a továbbiakban: F3DE 2017 kutatás). A kutatás célpopulációját a magyarországi hajléktalan populáció, a mintavételi keretet pedig a 2017-es F3 kutatás által az ország egész területén a hajléktalan-ellátás részeként müködő szálláshelyeken vagy közterületeken elért 8014 fös hajléktalan populáció képezte. A kutatás a mintavételi keretbe tartozó, az F3 kutatással elért hajléktalan személyek elérési helyszín (konkrét szálláshelyek és utcai szolgálatok) szerint rétegzett, egyhatodos véletlen mintáján történt ${ }^{3}$. A 2017-es F3 kutatás által elért 8014 fős mintakeret alapján az egyhatodos mintával dolgozó drogepidemiológiai kutatás kalkulált bruttó mintája 1335 fö volt, melynek a kutatás során 97,5\%-át, 1302 főt sikerült elérni. E mintanagyság mellett 95\%-os megbízhatósági szinten az elméleti hibahatár mértéke $\pm 2,5 \%$.

1. táblázat A mintakeretet jelentő $\mathrm{F} 3$ kutatással elért hajléktalanok és a drogepidemiológiai

kutatás mintájának nem és korcsoport szerinti megoszlása (\%)

\begin{tabular}{|c|c|c|c|c|c|c|}
\hline \multirow{2}{*}{ Korcsoport } & \multicolumn{3}{|c|}{ Mintakeret $(\mathrm{N}=7910)$} & \multicolumn{3}{|c|}{ Drogepidemiológiai minta $(N=1267)$} \\
\hline & Férfi & Nő & Összesen & Férfi & Nő & Összesen \\
\hline $18-34$ & 6,3 & 2,0 & 8,3 & 7,8 & 1,6 & 9,4 \\
\hline 34 felett & 70,1 & 21,6 & 91,7 & 69,8 & 20,8 & 90,6 \\
\hline Összesen & 76,4 & 23,6 & 100,0 & 77,7 & 22,3 & 100,0 \\
\hline
\end{tabular}

Forrás: F3 és F3DE 2017 kutatás

\footnotetext{
2 A „Február Harmadika” kutatássorozat keretében Budapesten 1999 óta (Bényei et al. 2000), vidéken 2006-tól minden év február 3-án adatfelvétel zajlik a hajléktalan emberek körében. A kutatás és a kutatást végző „Február 3. munkacsoport" nagy nemzetközi elismertséggel bír.

${ }^{3}$ A véletlen kiválasztás céljából az F3 kérdőíveket folyamatos sorszámozással láttuk el, majd az egyes adatfelvételi helyszínekhez (a kutatásban résztvevő szállókhoz, valamint utcai szolgálatokhoz) sorszámokat rendeltünk, a 2016-os F3 adatfelvétel során az adott helyszínen elért hajléktalanok száma, és/vagy az ott dolgozó munkatársak becslése alapján. Az egy-egy helyszínhez hozzárendelt sorszámokból SPSS program segítségével egyhatodos véletlen mintát vettünk és a véletlen mintába eső sorszámokról minden helyszín számára listát készítettünk. Ez a lista képezte a drogepidemiológiai vizsgálatba kerülők mintáját. A „kiválasztottak” beazonosítását az egyes adatfelvételi helyszíneken az F3 kérdőív felvételében közreműködő, a hajléktalan-ellátásban dolgozó szociális munkások végezték.
} 
A minta valamivel több mint egyharmadát átmeneti szállókon, 28,5\%-át éjjeli menedékhelyeken kérdezték. Az adatfelvétel idején egyéb intézménytípusban (hajléktalanok otthonában, rehabilitációs szállón, speciális menedékhelyen, lábadozóban, illetve egészségcentrumban) a mintába került személyek kevesebb mint tíz százaléka tartózkodott. A minta több mint egynegyedét pedig az utcai szolgálat érte el (1. ábra).

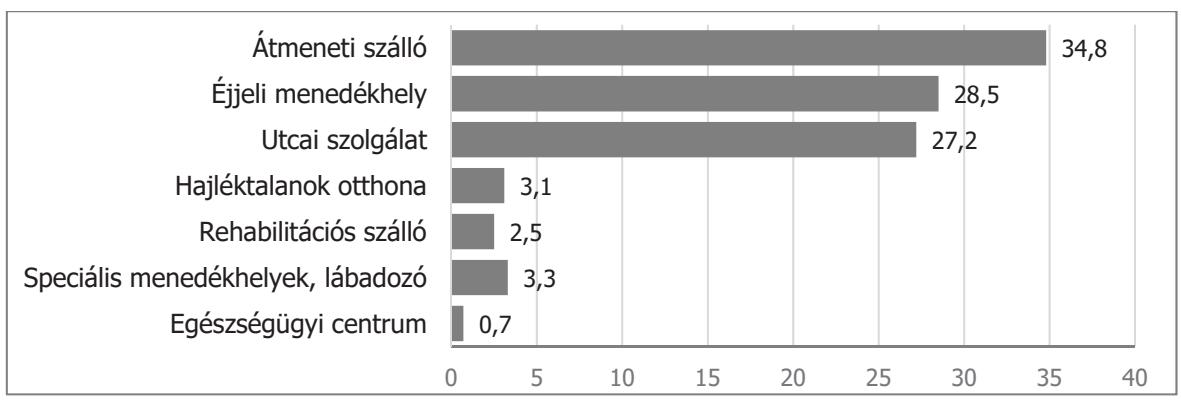

1. ábra A drogepidemiológiai kutatás mintájának intézménytípus szerinti eloszlása (\%) $(\mathrm{N}=1285)$

Forrás: F3DE 2017 kutatás

A megkérdezettek válaszolási hajlandóságának, illetve a válaszok megbízhatóságának növelése érdekében - a kutatás előzményének tekinthető 2007-es vizsgálathoz (Paksi et al. 2008, 2010) és más általános és speciális populációkon készült hazai drogepidemiológiai kutatásokhoz (Elekes - Paksi 2003, Paksi - Rózsa - Kun - Arnold - Demetrovics 2009, Paksi - Demetrovics - Magi - Felvinczi 2017, Paksi - Arnold 2009) hasonlóan - a pszichoaktív szerhasználattal kapcsolatos kérdések felvétele a megkérdezettnek külön zárható borítékban átadott önkitöltős kérdöívek alkalmazásával történt. A drogepidemiológiai adatfelvétel folyamatát a hajléktalan ellátásban dolgozó szociális munkások, illetve a nagyobb szálláshelyeken a helyszínre delegált drogszakmai civil szervezetek munkatársai segítették.

A pszichoaktív szerhasználattal kapcsolatos kérdések összeállítása során az EMCDDAmodell kérdőívét (EMQ) (EMCDDA 2002), az indikátor igényének változásait, és az új szerek (NPS) használatának nyomon követésére az általános populációs vizsgálatok vonatkozásában megfogalmazott ajánlásokat (EMCDDA 2015), valamint a kutatáshoz időben leginkább közelálló hazai általános populációs vizsgálat, az OLAAP 2015-ös kutatással (Paksi et al. 2017) és a tíz évvel korábban 2007-ben a hajléktalan populáción készült (Paksi et al. 2008, 2010) drogepidemiológiai vizsgálattal való összehasonlíthatóságot tartottuk szem előtt. 
2. táblázat A kutatás főbb módszertani jellemzőinek összefoglalása

\begin{tabular}{|l|l|}
\hline Célpopuláció & Magyarországi hajléktalan populáció \\
\hline Mintakeret & F3 vizsgálattal elért hajléktalan emberek (8014 fö) \\
\hline Mintaválasztás módja & Elérési helyenként rétegzett 1/6-os véletlen minta \\
\hline Mintanagyság & $\begin{array}{l}\text { Bruttó: } 1335 \text { fö Nettó: } 1302 \text { fö; }{ }^{4} \\
\text { F3 kutatással egyesített, súlyozott (kor/nem) minta: } 1042 \text { fö }^{\prime \prime}\end{array}$ \\
\hline Elméleti hibahatár & $\pm 2,5 \%$ (egyesített minta: $\pm 2,8 \%)$ \\
\hline Adatgyűjtési eljárás & Önkitöltős kérdöív \\
\hline Az adatfelvétel ideje & $\begin{array}{l}\text { Szállókon: } 2017 . \text { február 3; } \\
\text { Utcán: } 2017 . \text { február 3-10. }\end{array}$ \\
\hline Adatfelvétel eszköze & EMCDDA-minimumkérdések, OLAAP 2015 standard \\
\hline
\end{tabular}

Forrás: F3DE 2017 kutatás

\section{EREDMÉNYEK}

\subsection{A HAJLÉKTALAN POPULÁCIÓ TILTOTT DROGHASZNÁLATA 2017-BEN ${ }^{6}$}

\subsubsection{A droghasználat elterjedtsége}

A kutatás eredményei alapján Magyarországon a hajléktalan emberek egynegyede (a becslést terhelő standard hibát figyelembe véve 22,1-26,7\%) használt már életében valamilyen tiltott drogot ${ }^{7}$. A kutatást megelőző évben megközelítőleg minden hetedik (11,8-15,6\%), a kutatás elötti 30 napban pedig közel minden tizedik $(7,6-10,8 \%)$ hajléktalan ember fogyasztott valamilyen tiltott szert.

\footnotetext{
${ }^{4}$ Mivel a kutatás során minimális, a bruttó mintához képest mindössze 2,5\%-os mintakiesés történt, így a keretsokaság és a minta eloszlása tekintetében csak minimális eltérések mutatkoznak, így a minta súlyozását nem tartottuk szükségesnek, a drogepidemiológiai kutatás mintája súlyozás nélkül megfelelően reprezentálja az F3 kutatással elért hajléktalan emberek sokaságát.

5 Tekintettel arra, hogy a drogepidemiológiai vizsgálat kérdőíve - az életkor és nem kivételével - csak különböző pszichoaktív szerhasználattal kapcsolatos kérdéseket tartalmazott, a droghasználat társadalmi-demográfiai mintázódásához szükséges szociodemográfiai, illetve a hajléktalansággal összefüggő háttérváltozókat az F3 kutatás adatbázisából kapcsoltuk hozzá az drogepidemiológiai adatbázishoz. Az adatbázisok egyesítése során (az illesztéshez szükséges adatok esetében előforduló hiányzó információk miatt) a nettó mintához képest 20\%-os mintaveszteség történt. Az egyesített adatbázis 1042 fö adatait tartalmazza. Az egyesített minta esetében 95\%-os megbízhatósági szinten érvényes elméleti hibahatár - a teljes mintán érvényes hibahatárhoz képest - valamivel magasabb, $\pm 2,8 \%$. Az adatvesztés miatt az egyesített adatbázis a nettó mintához képest kismértékben torzult, így az egyesített adatbázist korcsoport és nem szerint a nettó mintával azonos összetételüvé tettük. A felhasznált súlyok minimumértéke 0,82 , maximuma pedig 1,07 .

${ }^{6}$ A prevalencia értékek és a droghasználat egyéb mutatóinak számítása során az EMQ (EMCDDA 2002) ajánlásait követtük.

7 Tiltott drogok közé a kutatás során a következő szereket soroltuk: kannabisz, szintetikus kannabisz, ecstasy, amfetamin, kokain, crack, új stimulánsok, heroin, más opiát, LSD, mágikus gomba, GHB, mefedron, intravénás drogok, egyéb drogok.
} 
A használat folyamatosságára utaló mutatók alapján azt mondhatjuk, hogy a valaha fogyasztók több mint egyharmada (32,8-44,8 \%-a) folyamatosan használ (több mint egy éve használt először és a kérdezést megelőző 12 hónapban is fogyasztott) tiltott drogokat. Ugyanilyen arányban vannak azok, akik már felhagytak a droghasználattal (kilépő), azaz a kérdezést megelőző 12 hónapban már nem fogyasztottak semmilyen tiltott szert. A valaha használók mintegy egyötöde pedig $(17,3-27,5)$ új belépő, azaz a kérdezést megelőzó évben használt elöször tiltott drogot (3. táblázat).

3. táblázat $A$ hajléktalan populáció drogérintettségének összefoglaló mutatói ${ }^{8}$

\begin{tabular}{|c|c|c|c|}
\hline \multicolumn{2}{|l|}{ Mutatók } & $\%$ & Standard hiba9 \\
\hline \multicolumn{2}{|c|}{ Tiltott drogok életprevalencia (LTP) értéke ( $N=1123$ ) } & 24,4 & $\pm 2,3$ \\
\hline \multirow{3}{*}{ Ebböl $(N=245)$} & Folyamatos használók & 38,8 & $\pm 6,0$ \\
\hline & Új belépők & 22,4 & $\pm 5,1$ \\
\hline & Kilépők aránya & 38,8 & $\pm 6,0$ \\
\hline \multicolumn{2}{|c|}{ Tiltott drogok éves prevalencia (LYP) értéke $(\mathrm{N}=1094)$} & 13,7 & $\pm 1,9$ \\
\hline \multicolumn{2}{|c|}{ Tiltott drogok havi prevalencia (LMP) értéke $(N=1098)$} & 9,2 & $\pm 1,6$ \\
\hline
\end{tabular}

Forrás: F3DE 2017 kutatás

A hajléktalan populációban az életprevalencia értékek alapján a legelterjedtebb tiltott drog a marihuána/hasis: minden ötödik-hatodik válaszoló fogyasztott már életében marihuánát, vagy hasist (LTP: 17,5; hiba: $\pm 2,0$ ). Ezzel hibahatáron belül azonos nagyságú az a populáció, aki a kannabisz származékokon kívül használt már egyéb tiltott drogokat is (LTP: 18,2; hiba: $\pm 2,1)$. A népszerüségi sorrendben a marihuána/hasist a szintetikus kannabisz (LTP: 13\%; hiba: $\pm 1,8)$, majd - a becslés hibáját figyelembe véve - azonos aránnyal az új stimulánsok, az ecstasy és az amfetamin származékok követik (LTP új stimulánsok: 9,7 ecstasy: 9,5 amfetamin: 8,3 hiba: $\pm 1,4$ és 1,6 között). Legnépszerübb szerek után jelentősen lemaradva következik az LSD és a kokain, melyeket - a hibahatárt figyelembe véve - a hajléktalan emberek 4-6\%-a próbálta már életében. Az összes többi vizsgált szer (heroin, egyéb opiátok, crack, GHB) mért életprevalencia értéke 2-4\% között mozog, azaz a megkérdezettek közül minden huszonötödik-ötvenedik próbálkozott ezekkel (2. ábra).

A közelmúltbeli (előző évi) használatban az egyéb tiltott drogok kapnak meghatározó szerepet: a hajléktalan emberek 11,9\%-a (hiba: \pm 1,5) fogyasztott marihuánán/hasison kívül valamilyen egyéb tiltott drogot is az elmúlt évben, míg a kannabisz származékok éves prevalencia értéke ennél szignifikánsan alacsonyabb, mindössze 7,8\% (hiba: $\pm 1,9$ ). A közelmúltbeli droghasználati struktúrában az új pszichoaktív szerek még dominánsabbá válnak: a szintetikus kannabisz kétharmados biztonsággal megelőzi a marihuána/hasis népszerüségét, és az új stimulánsok éves prevalencia értéke (LTP: 8,7 ; hiba: $\pm 1,6$ ) pedig szignifikánsan meghaladja - az

${ }^{8}$ A prevalencia értékek számítása során az EMQ (EMCDDA 2002) ajánlásainak megfelelően felmenő rendszerű inkonzisztencia korrekciót végeztünk.

9 95\%-os megbízhatósági szinten számított elméleti hibahatár (2SE). 
életprevalencia adatok alapján vele azonos népszerüségü - ecstasy és amfetamin használók arányát (LTP ecstasy 3,8; amfetamin: 3,3; hiba: $\pm 0,9$ ) (2. ábra).

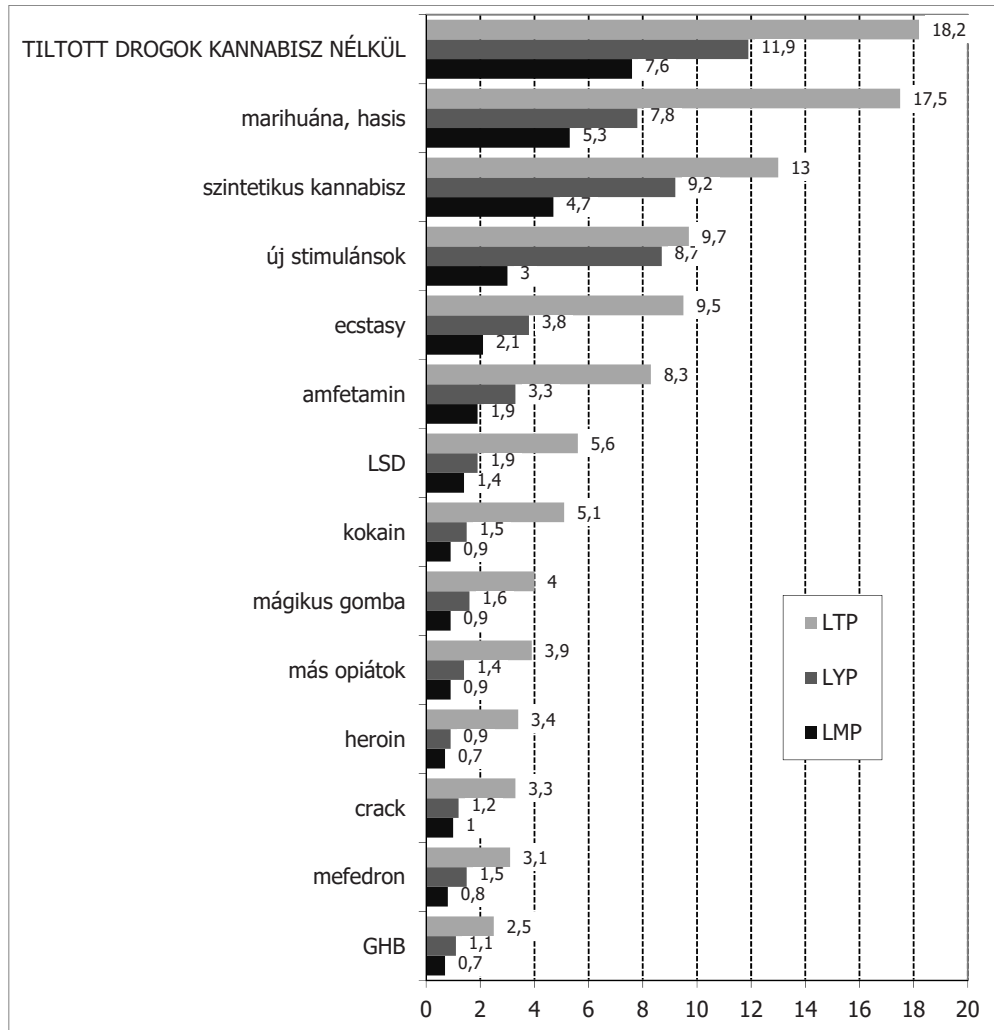

2. ábra A különböző tiltott drogok élet-, éves és havi prevalencia értéke a hajléktalan populációban (\%)

Forrás: F3DE 2017 kutatás

\subsubsection{Droghasználati piramis}

A legelterjedtebb tiltott szerek, a kannabisz, illetve a szintetikus kannabisz más droghasználó magatartásokhoz való kapcsolódásának vizsgálatára mindkét szerre építettünk egy-egy droghasználati piramist ${ }^{10}$. A két piramist együtt mutatjuk be a 3. ábrán.

\footnotetext{
${ }^{10} \mathrm{~A}$ hagyományosan a szakirodalomban az ún. tiltottdrog-fogyasztási piramist (EMCDDA 1999) a kannabisz származékok és más droghasználó magatartások kapcsolódásának kifejezésére konstruálják, ami az egyéb drogok életprevalencia értékét mutatja a marihuánát/hasist valaha fogyasztók körében. Tekintettel a szintetikus kannabiszhasználat nagyfokú elterjedtségére a hajléktalan populációban, a hagyományosan a kannabiszhasználókra épített droghasználati piramis speciális, a szintetikus kannabiszhasználókra épített változatát is megkonstruáltuk, ami az egyéb drogok életprevalencia értékét mutatja a szintetikus kannabiszt valaha fogyasztók körében
} 
A piramis fekete sávjaiból épül fel a hagyományos droghasználati piramis, amely azt mutatja, hogy azok, akik valaha életükben fogyasztottak kannabiszt, milyen arányban használtak egyéb drogokat (szintetikus kannabiszt, ecstasyt, új stimulánsokat, amfetamint, LSD-t, kokaint és/vagy heroint) is az életük során. A piramis alapján láthatjuk, hogy a hajléktalan népességben a valaha kannabiszt használók több mint fele használt már életében szintetikus kannabiszt, közel fele ecstasyt, mintegy kétötödük fogyasztott már valamilyen új stimulánst, illetve amfetamint, minden negyedik próbálkozott már élete során LSD-, illetve kokain- és közel minden ötödik heroinfogyasztással. Ezeket az értékeket összevetve a 2. ábrán szereplő életprevalencia értékekkel, láthatjuk, hogy a kannabiszt használók körében minden vizsgált drog életprevalencia értéke négy-hatszorosa a hajléktalan populációban mért életprevalencia értékeknek. A kannabiszt használók körében mintegy hatszor nagyobb az esélye a heroin, és kokain kipróbálásának, megközelítően ötszörös az LSD-, az amfetamin- vagy az ecstasyhasználat elöfordulásának, és négyszeres a valószínüsége annak, hogy fogyasztottak már szintetikus kannabiszt vagy új stimulánst, mint általában a hajléktalan népességben.

A szintetikus kannabiszhasználatra épített, a szürke sávokból felépülő droghasználati piramis - az új stimulánsok kivételével - leköveti a kannabiszhasználatra konstruált piramist, azzal a különbséggel, hogy a szintetikus kannabisz használók körében nem 4-6-szor, hanem 5-7-szer nagyobb az egyéb tiltott drogok használatának az esélye, és az új stimulánsok fogyasztása a kannabiszt használókhoz képest sokkal inkább elterjedt a szintetikus kannabisz használók körében.

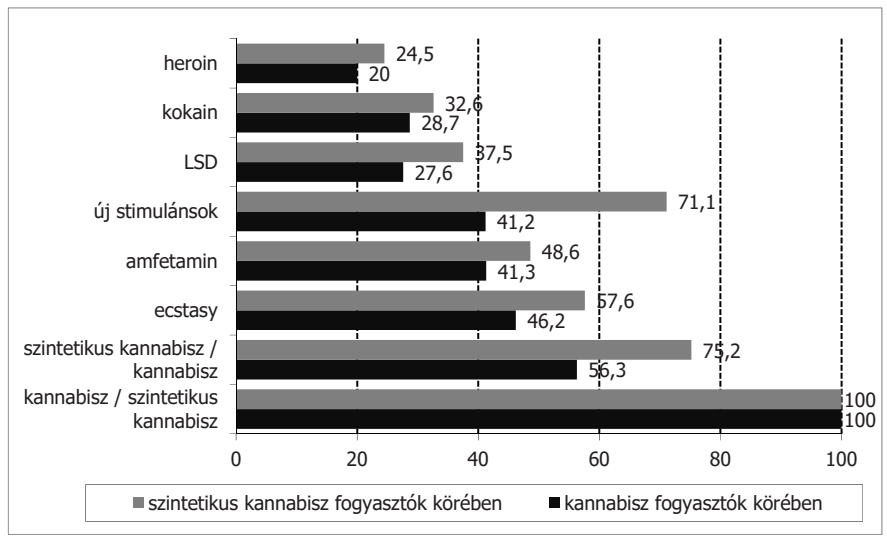

3. ábra Droghasználati piramis a hajléktalan populációban

(a kannabiszt, illetve szintetikus kannabiszt valaha fogyasztók \%-ában) ${ }^{11}$

Forrás: F3DE 2017 kutatás

Összességében tehát a kannabiszhasználatra és a szintetikus kannabisz használatra épített droghasználati piramis egyrészt azt jelzi, hogy a hajléktalan populációban mind a kannabiszhasználat, mind a szintetikus kannabisz használata erősen kapcsolódik az egyéb tiltott drogok

${ }^{11}$ A legelterjedtebb egyéb drogok életprevalencia értéke a kannabiszt, illetve szintetikus kannabiszt valaha fogyasztók körében. 
fogyasztásához. Emellett rámutat a kannabisz és a szintetikus kannabisz használat kapcsolódására: a kannabiszhasználó hajléktalan emberek körében a szintetikus kannabisz használat a leginkább elterjedt, a szintetikus kannabiszt használók körében pedig a kannabisz és az új stimulánsok népszerűsége a legnagyobb ${ }^{12}$. Az utóbbi az új pszichoaktív szerek használatának nagyfokú összekapcsolódását jelzi.

\subsubsection{Polydrog-használat ${ }^{13}$}

Mint ahogy a kannabiszfogyasztókra, illetve a szintetikus kannabisz használókra épített droghasználati piramis alapján is láttuk, a különböző tiltott drogok használata erős kapcsolódást mutat a hajléktalan populációban. Amennyiben azt vizsgáljuk, hogy az elmúlt évben valamilyen tiltott drogot használó hajléktalan emberek hányféle szert fogyasztottak, akkor azt láthatjuk, hogy kevesebb mint egynegyedre tehető azok aránya, akik a közelmúltban mindössze egyféle drogot használtak. A droghasználó hajléktalanok több mint háromnegyede tehát polydrog-használónak tekinthető, s egyharmaduk legalább négy-, minden tizenkettedik használó pedig nyolc- vagy többféle tiltott drogot próbált már ki (4. ábra).

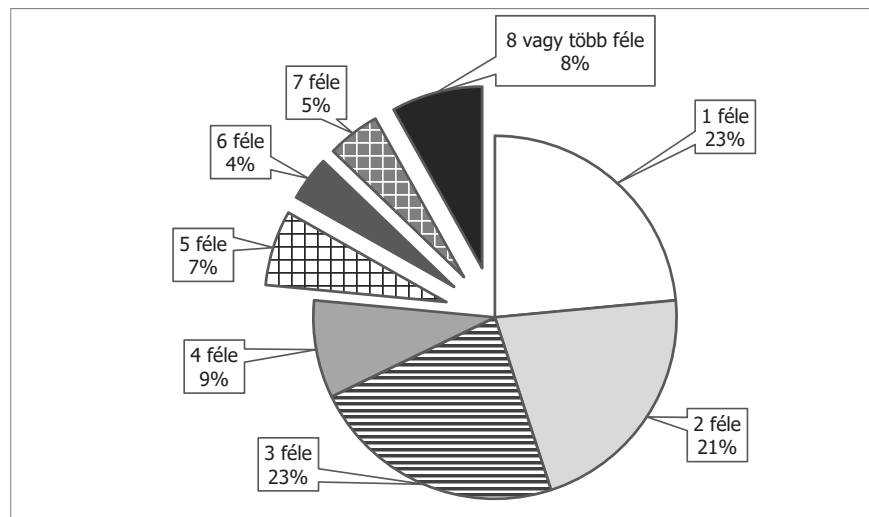

4. ábra A hajléktalan droghasználók polydrog-használata

(az elmúlt évben valamilyen tiltott drogot használók \%-ában)

Forrás: F3DE 2017 kutatás

\footnotetext{
${ }^{12}$ A szintetikus kannabisz használók körében a kannabisz és az új stimulánsok életprevalencia értékei hibahatáron belül megegyezik (a standard hiba nagysága az új stimulánsok esetében $\pm 5,9$, a kannabisz esetében $\pm 6,2$ ).

${ }^{13}$ A szakirodalom a polydrog-használat kifejezést több értelemben alkalmazza: „Több mint egy típusú pszichoaktív szer egyidejü vagy sorozatos fogyasztása egy személy által, általában egy másik szer hatását erősítendő vagy ellensúlyozandó céllal. Gyakran használják azon fogyasztók megkülönböztetésére, akiknek változatosabb a fogyasztási mintázatuk azoktól, akik kizárólag egyfajta kábítószert fogyasztanak. Általában többfajta illegális szer fogyasztásának leírására használják, de a kutatási irodalomban van, hogy egyszerűen legális drogok együttes használatára alkalmazzák, mint az alkohol és a dohány. A kategóriát azon alkalmakkor is alkalmazzák, amikor az elfogyasztott kábítószer pontos meghatározása nem lehetséges, vagy a fogyasztó maga sincs tisztában azzal, mit vett be..." http://drogfokuszpont.hu/fogalomtar/fogalomtar-ii/\#Politoxikom_nia_

Tanulmányunkban a „polydrog-használat” kifejezést a változatosabb fogyasztási mintázat értelemben alkalmazzuk.
} 


\subsubsection{Drogfogyasztás miatti problémák elöfordulása}

Azoknak a hajléktalan embereknek, akik használtak már az életük során valamilyen drogot, 33,9\%-a számolt be arról, hogy az életében volt olyan időszak, amikor a drogfogyasztás miatt fizikai és/vagy lelki problémái jelentkeztek, illetve személyes és/vagy intézményes kapcsolataiban megmutatkoztak a drogfogyasztás következményes károsodásai (ez a hajléktalan populáció egészére vetítve 8,6\%-os arányt jelent) (4. táblázat). A vizsgált hatféle probléma közül a valamilyen problémát jelzők több mint fele (58\%-a) egyféle problémáról számolt be. A leggyakrabban említett problémák rendőrségi (15,3\%), családi (14,5\%), testi (13,7\%), illetve lelki $(13,3 \%)$ jellegüek.

A droghasználó hajléktalanok droghasználattal kapcsolatos kezelési igényét jelzi, hogy tízből hárman (29,7\%, ami a hajléktalan populációra vetítve 7,7\%-os arányt jelent) megjelentek a droghasználatukkal összefüggésben az életük során járó- és/vagy fekvőbeteg egészségügyi ellátásban. Az elmúlt évi kezelési igény elsősorban a járóbeteg-ellátásban jelentkezett. Életük során a droghasználó hajléktalanok valamivel több mint egynegyedének volt droghasználattal összefüggésben rendőrségi ügye, az elmúlt évben pedig egytizedüknek (az arányok a hajléktalan populációra értelmezve 6,4\%, illetve 2,2\%) (4. táblázat).

4. táblázat A drogfogyasztás miatti problémák előfordulása a hajléktalan droghasználók körében (\%)

\begin{tabular}{|l|c|c|}
\hline & valaha & elmúlt évben \\
\hline $\begin{array}{l}\text { Drogfogyasztása miatt valamilyen (testi/lelki/családi/ kapcsolati/ } \\
\text { munkahelyi/iskolai/rendőrségi) problémája volt }\end{array}$ & 33,9 & - \\
\hline Drogproblémái miatt járóbeteg-ellátásban részesült & 25,0 & 12,9 \\
\hline Drogproblémái miatt fekvőbeteg-ellátásban részesült & 22,3 & 7,8 \\
\hline Droggal kapcsolatos rendőrségi ügye volt & 26,7 & 9,8 \\
\hline
\end{tabular}

Forrás: F3DE 2017 kutatás

\subsubsection{A droghasználó hajléktalanok társadalmi jellemzői}

A droghasználat társadalmi mintázódását néhány olyan általános szociodemográfiai változó mentén vizsgáltuk, mint a nem, az életkor, az iskolai végzettség, régió, roma kisebbséghez való tartozás. Emellett bevontunk az elemzésbe néhány speciálisan a hajléktalan léthez kötődő, a helyhasználattal, illetve jövedelemszerzéssel kapcsolatos változót is.

A társadalmi elhelyezkedés vizsgált alapvető változói közül az iskolai végzettség kivételével minden dimenzió mentén szignifikáns mintázódás bontakozott ki. A férfiak, a fiatal felnőttek, a Dél-Dunántúli régióban, illetve Pest megyében élő hajléktalan emberek, továbbá azok körében, akikre „mondták már, hogy cigány”, szignifikánsan az átlagosnál magasabb életprevalencia értéket mértünk. A leginkább robosztus különbség a fiatal felnőtt és az annál idősebbek kockázataiban mutatkozik meg: a fiatal felnőttek életprevalencia értéke több mint háromszorosa az idősebbekének. Kétszer, illetve közel kétszer nagyobb a valaha használók aránya a férfiaknak körében, illetve azok esetében, akiket a környezete romaként jellemez. A drogfogyasztásnak a hajléktalan élethelyzet speciális jellemzőivel való kapcsolatát vizsgálva a kutatás adatai 
azt mutatják, hogy - az adatfelvétel időpontjában - az utcán élő hajléktalanok körében szignifikánsan, mintegy másfélszer nagyobb a droghasználati tapasztalattal rendelkezők aránya: az ellátásban lévő és az utcán élő hajléktalanok között vidéken és a fövárosban is szignifikáns $(p<0,001)$ különbség tapasztalható, s a leginkább érintett a fóvárosban utcán elért populáció, ahol a válaszolók mintegy kétötöde (LTP: 39,1) fogyasztott már életében, és közel egyharmada az elmúlt hónapban (LYP: 30,4) is használt valamilyen tiltott drogot (5. táblázat).

5. táblázat A tiltott drogok életprevalencia értékének mintázódása a különböző

társadalmi-demográfiai háttérváltozók mentén a hajléktalan populációban (a válaszolók \%-ában)

\begin{tabular}{|c|c|c|c|c|}
\hline Vátozók & Változóértékek & $\mathrm{N}$ & LTP & sig \\
\hline \multirow{2}{*}{ Nem } & ffi & 864 & 27,4 & \multirow{2}{*}{$<0,001$} \\
\hline & nő & 242 & 13,2 & \\
\hline \multirow{2}{*}{ Életkor } & $18-34$ & 111 & 65,8 & \multirow{2}{*}{$<0,001$} \\
\hline & $35-64$ & 989 & 19,5 & \\
\hline \multirow{5}{*}{ Iskolai végzettség } & $<8$ ált & 77 & 28,6 & \multirow{5}{*}{ n. sz. } \\
\hline & 8 ált & 334 & 26,9 & \\
\hline & szakmunkás/szakiskola & 345 & 20,9 & \\
\hline & érettségi & 106 & 21,7 & \\
\hline & föiskola/egyetem & 23 & 8,7 & \\
\hline \multirow{8}{*}{ Régió } & $\mathrm{Bp}(\mathrm{KMO})$ & 350 & 22,9 & \multirow{8}{*}{0,019} \\
\hline & Nyugat-Dunántúl & 62 & 29 & \\
\hline & Közép-Dunántúl & 122 & 23 & \\
\hline & Dél-Dunántúl & 87 & 32,2 & \\
\hline & Dél-Alföld & 59 & 20,3 & \\
\hline & Észak-Alföld & 79 & 22,8 & \\
\hline & Észak-Magyarország & 115 & 15,7 & \\
\hline & Pest-megye (KMO) & 20 & 50,0 & \\
\hline \multirow{2}{*}{ Roma* } & igen & 287 & 32,4 & \multirow{2}{*}{$<0,001$} \\
\hline & nem & 581 & 18,9 & \\
\hline \multirow{2}{*}{ Helyszín } & szálló & 804 & 20,4 & \multirow{2}{*}{$<0,001$} \\
\hline & utca & 303 & 35,0 & \\
\hline \multicolumn{5}{|c|}{ * Mondták-e Önre, hogy cigány? } \\
\hline \multicolumn{5}{|c|}{$\begin{array}{l}\text { A szignifikánsan nagyobb kockázatú csoportok prevalencia értékeit } \\
\text { vastagítással kiemeltük. }\end{array}$} \\
\hline
\end{tabular}

Forrás: F3DE 2017 kutatás

Azok a hajléktalan emberek, akik használtak már valamilyen tiltott szert az életük során, az átlag hajléktalanokhoz képes szignifikánsan nagyobb arányban élnek kéregetésből, illetve 
gyűjtögetésből, kukázásból, és ezek egyben a droghasználó hajléktalanok leginkább jellemző megélhetési formái is (6. táblázat).

6. táblázat $A$ különböző jövedelemforrások említése a drogot valaha használók, és nem használók között, \% $(\mathrm{N}=895)$

\begin{tabular}{|l|c|c|c|}
\hline \multirow{2}{*}{$\begin{array}{l}\text { Miböl élt? - kérdésre az adott lehetöséget } \\
\text { jelölök aránya }\end{array}$} & \multicolumn{2}{|c|}{$\begin{array}{r}\text { fogyasztott-e már valamilyen } \\
\text { tiltott drogot }\end{array}$} & \multirow{2}{*}{ sig } \\
\cline { 2 - 3 } & nem fogyasztott & fogyasztott & \\
\hline rendszeres munkából & 14,8 & 14,2 & nsz \\
\hline közmunkából & 8,5 & 6,1 & nsz \\
\hline munkanélküli ellátásból & 4,2 & 3,3 & nsz \\
\hline öregség/özvegyi nyugdíjból & 12,6 & 1,9 & $\mathrm{p}<0,001$ \\
\hline rokkantsági nyugdíjból & 15,0 & 5,7 & $\mathrm{p}<0,001$ \\
\hline önkormányzati segélyből, RSZS, FHT & 14,8 & 17,0 & $\mathrm{nsz,}$ \\
\hline gyesből, gyedből, táppénzből & 0,9 & 0,5 & $\mathrm{nsz}$ \\
\hline kéregetésből, koldulásból & 7,5 & $\mathbf{1 9 , 8}$ & $\mathrm{p}<0,001$ \\
\hline gyűjtögetésből, kukázásból & 11,3 & $\mathbf{2 2 , 1}$ & $\mathrm{p}<0,001$ \\
\hline nem volt pénze (mások segítették) & 10,0 & 10,4 & $\mathrm{nsz}$ \\
\hline A szignifikánsan nagyobb kockázatú csoportok prevalencia értékeit vastagítással kiemeltük. \\
\hline
\end{tabular}

Forrás: F3DE 2017 kutatás

Amennyiben a fenti társadalmi-demográfiai jellemzőket a folyamatos droghasználattal összefüggésben vizsgáljuk, akkor a fiatal felnőtt életkor, a roma kisebbséghez tartozás, illetve az utcán való lét azok a jellemzők, melyek mentén a drogfogyasztók között szignifikánsan nagyobb a folyamatos droghasználat előfordulása. Azok a droghasználó hajléktalanok pedig, akik idősebbek és/vagy szállón élnek, valamint akiket a környezete nem romának tart, nagyobb eséllyel lépnek ki a droghasználatból (7. táblázat). A jövedelemforrások tekintetében a tiltott szereket a közelmúltban is használók (folyamatos használó és új belépők) körében szignifikánsan gyakoribb a „kéregetés, koldulás” előfordulása, illetve az, hogy mások támogatásával élnek. 
7. táblázat $\mathrm{A}$ folyamatos droghasználat társadalmi mintázódása

(a valaha valamilyen tiltott drogot használók \%-ában)

\begin{tabular}{|c|c|c|c|c|c|c|}
\hline Vátozók & Változóértékek & $\mathrm{N}$ & Új belépő & Kilépő & $\begin{array}{l}\text { Folyamatos } \\
\text { használó }\end{array}$ & sig \\
\hline \multirow[t]{2}{*}{ Nem } & ffi & 209 & 22,0 & 38,8 & 39,2 & \multirow{2}{*}{ n. sz. } \\
\hline & nő & 31 & 22,6 & 38,7 & 38,7 & \\
\hline \multirow[t]{2}{*}{ Életkor } & $18-34$ & 66 & 24,2 & 18,2 & 57,6 & \multirow{2}{*}{$<0,001$} \\
\hline & $35-64$ & 172 & 20,3 & 46,5 & 33,1 & \\
\hline \multirow{5}{*}{$\begin{array}{l}\text { Iskolai } \\
\text { végzettség }\end{array}$} & $<8$ ált & 17 & 17,6 & 29,4 & 52,9 & \multirow{5}{*}{ n. sz. } \\
\hline & 8 ált & 80 & 23,8 & 35,0 & 41,3 & \\
\hline & szakmunkás/szakiskola & 66 & 18,2 & 47,0 & 34,8 & \\
\hline & érettségi & 20 & 20,0 & 30,0 & 50,0 & \\
\hline & föiskola/egyetem & 2 & 50,0 & 50,0 & 0,0 & \\
\hline \multirow[t]{2}{*}{ Helyszín } & szálló & 143 & 23,1 & 44,8 & 32,2 & \multirow{2}{*}{$=0,043$} \\
\hline & utca & 98 & 22,4 & 30,6 & 46,7 & \\
\hline \multirow[t]{8}{*}{ Régió } & Bp. $(K M O)$ & 69 & 23,2 & 27,5 & 49,3 & \multirow{8}{*}{$=0,066$} \\
\hline & Nyugat-Dunántúl & 17 & 5,9 & 58,8 & 35,3 & \\
\hline & Közép-Dunántúl & 24 & 16,7 & 54,2 & 29,2 & \\
\hline & Dél-Dunántúl & 22 & 22,7 & 27,3 & 50,0 & \\
\hline & Dél-Alföld & 12 & 25,0 & 66,7 & 8,3 & \\
\hline & Észak-Alföld & 16 & 25,0 & 50,0 & 25,0 & \\
\hline & Észak-Magyarország & 17 & 23,5 & 47,1 & 29,4 & \\
\hline & Pest megye (KMO) & 10 & 30,0 & 10,0 & 60,0 & \\
\hline \multirow[t]{2}{*}{ Roma* } & igen & 81 & 23,5 & 24,7 & 51,9 & \multirow{2}{*}{$=0,006$} \\
\hline & nem & 98 & 17,3 & 51,0 & 31,6 & \\
\hline \multicolumn{7}{|c|}{ *Mondták-e Önre, hogy cigány? } \\
\hline A szignifi & an nagyobb kockázatı & $\mathrm{kpr}$ & ncia ért & astag & I kiemeltük. & \\
\hline
\end{tabular}

Forrás: F3DE 2017 kutatás

\subsubsection{Mi volt elöbb? - az első droghasználat életkora}

A droghasználó hajléktalanok átlagosan 21,8 éves korban próbáltak ki először valamilyen tiltott drogot. A valaha használók fele (50,8\%) azonban 18 éves korára túl volt az első droghasználaton, s egyharmaduk pedig 16 évesen, vagy annál fiatalabb korban használt először valamilyen tiltott drogot. Legkorábban 9 évesen történt az első használat. 
Az első tiltott drogfogyasztás életkora alapján felrajzolt kumuláltprevalencia-görbe ${ }^{14}$ (5. ábra) azt mutatja, hogy a hajléktalan populáció körében a drogkipróbálók aránya 13 és 20 éves kor között egyenletesen, évente 1-2\%-kal emelkedett, majd a kapcsolatba kerülés kockázata csökkent, 20-25 éves kor között évente átlagosan fél százalék körül mozgott. Az ezt követő harminc évben minimalizálódott a szerek kipróbálása (egy-egy korévben, pl. 30, illetve 40 éves korban még előfordult 1-1\%-os kockázat, azonban 25-54 éves kor között a kipróbálás évi átlagos kockázata mindössze 0,1\% volt), 54 éves kort követően pedig megszünt.

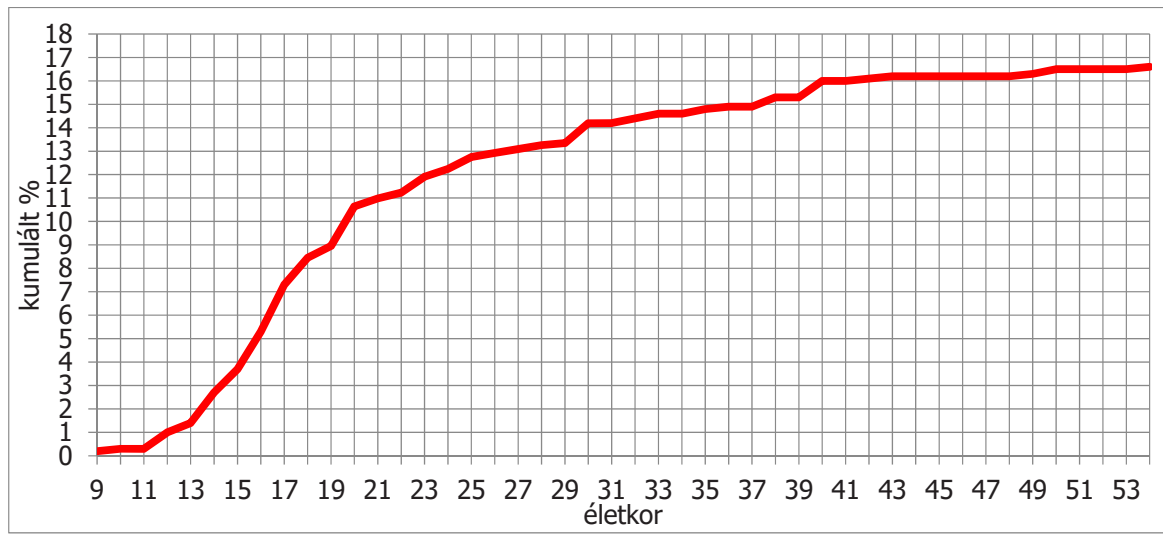

5. ábra A tiltott drogfogyasztás kumuláltprevalencia-görbéje a hajléktalanok körében

(a kérdésre válaszolók százalékában, $\mathrm{N}=987$ )

Forrás: F3DE 2017 kutatás

Az első droghasználat fentiekben bemutatott életkori jellemzői, valamint a megkérdezettek arra vonatkozó emlékei alapján, hogy - amennyiben hajléktalannak tartja magát - hány éve vált hajléktalanná, megpróbáltuk megválaszolni, a klasszikus „tyúk vagy tojás” problémát, azt, hogy a droghasználó hajléktalanok esetében a hajléktalanná válás előzte-e meg a droghasználatot, vagy a droghasználat a hajléktalanná válást ${ }^{15}$. Természetesen az összefüggés vizsgálata csak a két helyzet időbelisége, s nem az ok-okozati reláció vonatkozásában szolgál információval.

A 9. táblázatban szereplő eloszlások alapján láthatjuk, hogy azokban az esetekben, akiknél az első droghasználat idejét és a hajléktalanná válás évét is ismerjük ${ }^{16}$, a válaszolók $82 \%$-a hajléktalanná válását megelőzően használt már valamilyen tiltott drogot, és elenyésző $(5,1 \%)$ azok aránya, akik esetében az első droghasználat a hajléktalanná válást követően történt.

\footnotetext{
${ }^{14}$ Amennyiben valamely populációban az első droghasználat évére vonatkozó gyakorisági adatok kumulált értékeit ábrázoljuk, a görbe meredeksége a populáció drogokkal való kapcsolatba kerülésének, azaz az életprevalencia érték növekedésének kockázatát mutatja a különböző életkorokban.

${ }^{15}$ A hajléktalanná válás pontos évét csak az elmúlt 9 év vonatkozásában ismertetjük. Ennél régebben hajléktalanként élők esetében csak összevont adatokkal rendelkezünk (10-15 éve; több mint 15 éve). Ez azok esetében, akik legalább 10 éve használtak először drogot, az „azonos évben/időszakban” kategóriába tartozók arányát növeli.

${ }^{16}$ A droghasználók 44,7-a esetében az első droghasználat, és/vagy a hajléktalanná válás időpontját nem ismerjük.
} 
8. táblázat Az első droghasználat és a hajléktalanná válás időbeli sorrendje (a droghasználók ( $N=213)$, illetve a mindkét kérdésre válaszolók ( $N=118)$ százalékában)

\begin{tabular}{|l|c|}
\hline MI VOLT ELŐBB? & $\begin{array}{c}\text { Válaszoló* } \\
\text { droghasználók \%-ában }\end{array}$ \\
\hline Már hajléktalan volt, mikor kipróbált valamilyen tiltott drogot & 5,1 \\
\hline Hajléktalanná válása előtt használt valamilyen tiltott drogot & 81,2 \\
\hline A hajléktalanná válással azonos évben használt először tiltott drogot & 13,7 \\
\hline Válaszoló droghasználók & 100,0 \\
\hline Az összes droghasználó & - \\
\hline $\begin{array}{l}\text { * Az első droghasználat és a hajléktalanná válás kérdésére is válaszoló } \\
\text { droghasználók. }\end{array}$ \\
\hline
\end{tabular}

Forrás: F3DE 2017 kutatás

\subsection{A hajléktalan populáció egyéb pszichoaktív szerhasználata}

\subsubsection{Az egyéb pszichoaktiv szerhasználat elterjedtsége}

Az egyéb pszichoaktív szerek közül a hajléktalan populációban a dohányzás a leginkább elterjedt. A hajléktalan emberek több mint négyötöde $(83,1 \%$ hiba: $\pm 1,9)$ aktuálisan dohányzik, $75,2 \%$-uk rendszeresen (naponta), és a legtöbben napi egy doboz, átlagosan 16,6 szál cigarettát szívnak el.

A hajléktalan emberek túlnyomó többsége a közelmúltban vagy aktuálisan fogyasztott alkoholt: több mint háromnegyede $(79,2 \%$ hiba: $\pm 2,1)$ az elmúlt évben, kétharmaduk $(65,6 \%$ hiba: $\pm 2,4)$ az elmúlt hónapban is ivott. Az alkoholfogyasztás excesszív formáira utaló részegségig való ivás, illetve rohamivás mintegy háromötödükkel fordult elő a kutatást megelőző évben. A kutatás eredményei alapján a dohányzáshoz képest alkoholfogyasztás napi szinten kevésbé érinti a hajléktalan populációt, körülbelül egynegyedük iszik naponta, vagy majdnem naponta $(26,5 \%$ hiba: $\pm 2,2)$.

Nyugtatót/altatót a közelmúltban a hajléktalan populáció valamivel több mint egyharmada (LYP: 34,5; hiba: $\pm 2,4$ ) fogyasztott, aktuálisan pedig mintegy egynegyede használt (LMP: 28,8; hiba: $\pm 2,1)$. Az utolsó használat adatai alapján a hajléktalan emberek többnyire orvosi rendelvényre fogyasztanak altatót vagy nyugtatót, az orvosi rendelvény nélküli használat a fogyasztók mintegy egynegyedére jellemző (ez a populáció 9,9\%-a).

Az inhalánsok és az anabolikus szteroidok használata kevéssé jellemző a hajléktalan populációban. Ugyan 7,9\%-uk szipuzott már életében, de a közelmúltbeli, illetve az aktuális használat más pszichoaktív szerek elterjedtségéhez képest alacsonynak mondható. 
9. táblázat A hajléktalan populáció egyéb pszichoaktív szerhasználat elterjedtségére vonatkozó összefoglaló mutatók

\begin{tabular}{|c|c|c|}
\hline & $\%$ & Standard hiba \\
\hline \multicolumn{3}{|l|}{ ALKOHOLFOGYASZTÁS } \\
\hline Alkoholfogyasztás éves prevalencia $(N=1260)$ & 79,2 & $\pm 2,1$ \\
\hline Alkoholfogyasztás havi prevalencia $(N=1252)$ & 65,6 & $\pm 2,4$ \\
\hline $\begin{array}{l}\text { Az elmúlt hónapban minden nap, vagy majdnem minden nap } \\
\text { ivott }(N=1249)\end{array}$ & 26,5 & $\pm 2,2$ \\
\hline Berúgás éves prevalencia $(N=1200)$ & 58,3 & $\pm 2,6$ \\
\hline Berúgás havi prevalencia $(\mathrm{N}=1217)$ & 35,5 & $\pm 2,5$ \\
\hline Elmúlt hónapban legalább 3 alkalommal volt részeg & 24,3 & $\pm 2,2$ \\
\hline Rohamivás* éves prevalencia $(\mathrm{N}=1248)$ & 58,8 & $\pm 2,5$ \\
\hline \multicolumn{3}{|l|}{ DOHÁNYZÁS } \\
\hline Dohányzik ( $N=1257)$ & 83,1 & $\pm 1,9$ \\
\hline Napi cigarettamennyiség (szál; átlag/módusz) & $16,6 / 20$ & \\
\hline \multicolumn{3}{|l|}{ INHALÁNS HASZNÁLAT } \\
\hline Inhaláns használat életprevalencia $(\mathrm{N}=1159)$ & 7,9 & $\pm 1,4$ \\
\hline Inhaláns használat éves prevalencia $(\mathrm{N}=1158)$ & 2,6 & $\pm 0,8$ \\
\hline Inhaláns használat havi prevalencia $(\mathrm{N}=1165)$ & 2,2 & $\pm 0,8$ \\
\hline \multicolumn{3}{|l|}{ ANABOLIKUS SZTEROIDOK HASZNÁLATA } \\
\hline Anabolikus szteroidok életprevalencia $(\mathrm{N}=1129)$ & 2,5 & $\pm 0,8$ \\
\hline Anabolikus szteroidok éves prevalencia $(\mathrm{N}=1129)$ & 1,3 & $\pm 0,6$ \\
\hline Anabolikus szteroidok havi prevalencia $(\mathrm{N}=1142)$ & 0,9 & $\pm 0,5$ \\
\hline \multicolumn{3}{|l|}{ NYUGTATÓ/ALTATÓHASZNÁLAT } \\
\hline Nyugtató/altatóhasználat életprevalencia $(N=1241)$ & 39,6 & $\pm 2,5$ \\
\hline Nyugtató/altatóhasználat éves prevalencia ( $N=1241)$ & 34,5 & $\pm 2,4$ \\
\hline Nyugtató/altatóhasználat havi prevalencia $(\mathrm{N}=1254)$ & 28,8 & $\pm 2,1$ \\
\hline $\begin{array}{l}\text { Az utolsó nyugtató/altatóhasználat alkalmával orvosi rendelvény } \\
\text { nélkül használók aránya }(\mathrm{N}=484)\end{array}$ & 26,3 & $\pm 3,8$ \\
\hline
\end{tabular}

Forrás: F3DE 2017 kutatás 


\subsubsection{Az egyéb pszichoaktív szerhasználattal kapcsolatos problémák}

Annak ellenére, hogy a hajléktalan populációban a különböző pszichoaktív szerhasználó magatartások közül a dohányzás a leginkább elterjedt, a legtöbb problémát az alkoholfogyasztással kapcsolatban jelezték a megkérdezettek (10. táblázat). A hajléktalan emberek közel felének $(45,9 \%)$ volt olyan időszak az éltében, amikor az alkoholfogyasztás miatt fizikai és/vagy lelki problémái jelentkeztek, illetve személyes és/vagy intézményes kapcsolataiban megmutatkoztak az alkoholfogyasztás következményes károsodásai. A vizsgált hatféle probléma közül a valamilyen problémát jelzők közel kétharmada (63,6\%-a) egyféle problémáról számolt be. A leggyakrabban említett problémák sorrendben a családi (20,7\%), testi (17,5\%), rendőrségi (15\%), illetve lelki (14,9\%) jellegü problémák.

A hajléktalan populáció alkoholfogyasztással kapcsolatos kezelési igényét jelzi, hogy több mint egyharmaduk (34,9\%) megjelent élete során járó- vagy fekvőbeteg egészségügyi ellátásban - többségük mind a kettőben - alkoholproblémákkal.

Az alkoholfogyasztással összefüggő problémák és ellátási igények gyakorisága a hajléktalan populációban jelentősen meghaladja populációs szinten a drogfogyasztás miatti problémák előfordulását.

A dohányzással, illetve altató/nyugtatófogyasztással összefüggésben - az alkoholfogyasztáshoz képest - jóval ritkábban jeleztek problémát a megkérdezettek, bár a droghasználattal összefüggésben jelzett problémák populációs arányához (8,6\%) képest ezek is jóval nagyobb gyakoriságúak.

10. táblázat Az egyéb pszichoaktív szerhasználat miatti problémák előfordulása a hajléktalan populációban (a válaszolók százalékában)

\begin{tabular}{|l|c|c|}
\hline & Valaha & Elmúlt évben \\
\hline $\begin{array}{l}\text { Dohányzása miatt valamilyen (testi/lelki/családi/kapcsolati/ } \\
\text { munkahelyi(iskolai)/rendőrségi) problémája volt }\end{array}$ & 19,1 & - \\
\hline $\begin{array}{l}\text { Altató/nyugtató fogyasztása miatt valamilyen (testi/lelki/családi/ } \\
\text { kapcsolati/munkahelyi(iskolai)/rendőrségi) problémája volt }\end{array}$ & 13,4 & - \\
\hline $\begin{array}{l}\text { Alkoholfogyasztása miatt valamilyen (testi/lelki/családi/kapcsolati/ } \\
\text { munkahelyi(iskolai)/rendőrségi) problémája volt }\end{array}$ & 45,9 & - \\
\hline Alkoholfogyasztása miatt járóbeteg-ellátásban részesült & 28,3 & 11,0 \\
\hline Alkoholfogyasztása miatt fekvőbeteg-ellátásban részesült & 27,2 & 7,0 \\
\hline Alkoholfogyasztással kapcsolatos rendőrségi ügye volt & 35,6 & 7,9 \\
\hline
\end{tabular}

Forrás: F3DE 2017 kutatás 


\section{A HAJLÉKTALAN POPULÁCIÓ PSZICHOAKTÍV SZERHASZNÁLATI SZOKÁSAIBAN MEGJELENŐ TENDENCIÁK}

A tendenciák felvázolása során a 2017-es kutatás adatait a hajléktalanok körében 2007-ben készült drogepidemiológiai kutatás (Paksi et al. 2008, 2010) eredményeivel hasonlítjuk össze. Tekintettel arra, hogy a 2007-es kutatás a fővárosi ellátásban részesülő hajléktalan populáció reprezentatív mintáján készült, ezért az összehasonlítás során a 2017-es kutatás mintájából is csak a fővárosi ellátóhelyeken elért hajléktalanok leszelektált 417 fös mintáját használjuk ${ }^{17}$.

\subsubsection{A droghasználat elterjedtségének változása a hajléktalan populációban}

A fővárosi, ellátásban részesülő hajléktalanok körében a tiltott drogok életprevalencia értéke a 2017-es vizsgálatban $21,7 \%$, az éves prevalencia $12,8 \%$, a havi prevalencia pedig 7,9\%. Ezeket az értékeket összehasonlítva a 2007-es eredményekkel, mérés hibahatárát figyelembe véve (11. táblázat) azt mondhatjuk, hogy a fővárosi ellátásban részesülő hajléktalanok körében kétharmados biztonsággal növekedett azok aránya, akik az életük során kipróbáltak valamilyen tiltott drogot. Ugyanakkor a 10 évvel korábban mért rövidebb idejü prevalencia értékek hibahatáron belül azonosak a jelenlegi vizsgálatban kapott eredményekkel.

11. táblázat $A$ tiltott drogfogyasztás elterjedtsége ${ }^{18}$ a budapesti ellátásban részesülő hajléktalan populációban 2007-ben és 2017-ben (a válaszolók \%-ában)

\begin{tabular}{|l|c|c|c|c|c|c|}
\hline Mutatók & N & $\begin{array}{c}\text { 2007-ben } \\
(\%)\end{array}$ & Standard hiba & N & $\begin{array}{c}\text { 2017-ben } \\
(\%)\end{array}$ & Standard hiba \\
\hline Tiltott drogok LTP & 411 & 16,3 & $\pm 3,3$ & 341 & 21,7 & $\pm 4,1$ \\
\hline Tiltott drogok LYP & 400 & 10,3 & $\pm 2,8$ & 329 & 12,8 & $\pm 3,4$ \\
\hline Tiltott drogok LMP & 418 & 8,6 & $\pm 2,4$ & 331 & 7,9 & $\pm 2,7$ \\
\hline
\end{tabular}

Forrás: Paksi et al. (2010); F3DE 2017 kutatás

A szerenkénti életprevalencia értékek alapján kétharmados biztonsággal minden vizsgált tiltott drog esetében elmondhatjuk, hogy növekedett a kipróbálók tábora a fövárosi, ellátás-

\footnotetext{
${ }^{17}$ A 2017-es F3 kutatás a fővárosi ellátóhelyeken összesen 2553 föt ért el. Ez a 2017-es drogepidemiológiai kutatás fővárosi, ellátásban részesülő almintájának a célpopulációja, ami azt jelenti, hogy a drogepidemiológiai vizsgálat ezen szegmensében a bruttó minta nagysága 425,4 fő volt, így a 417 fős nettó mintanagyság 98\%-os mintaelérést jelent.

${ }^{18}$ A 2007-es kutatás során a tiltott szerek közé az alábbiakat soroltuk: marihuána/hasis, LSD, mágikus gomba, amfetamin, ecstasy, kokain, heroin, más opiátok (pl. máktea, kodein), herbál drogok, crack, rush, angyalpor, GHB, bármilyen drog intravénásan, valami más (általunk fel nem sorolt) drog. A megkérdezett szerek csak részben fednek át a 2017-es kutatásban vizsgált szerekkel: a 2007-ben vizsgált szerek közül a 2017-es kutatásban nem szerepeltek herbál drogok, a rush, az angyalpor és az l-por, ugyanakkor szerepelt a szintetikus kannabisz, az új stimulánsok, és a mefedron. A vizsgálat szerek körének különbözősége ellenére az összesített prevalencia értékek összehasonlítását az teszi lehetővé, hogy a kérdőívben konkrétan megnevezett szerek mellett mindkét vizsgálatban szerepelt a „valami más drog"-ra vonatkozó kérdés, ahol a kérdezett megjelölhetett minden olyan drog fogyasztását, ami nem került név szerint megkérdezésre, és az arra adott választ az összesített prevalencia érték tartalmazza.
} 
ban részesülő hajléktalanok körében. A mindkét kutatásban vizsgált tiltott drogok preferencia sorrendje ugyanakkor a szerenkénti prevalencia értékek növekedése mellett is gyakorlatilag megegyezik ${ }^{19}$, a hagyományos tiltott drogok között stabilan a legnépszerübb a marihuána/ hasis, ezt követi ecstasy és az amfetamin (6. ábra).

Ha azonban a korábbi kutatásban nem szereplő új pszichoaktív szereket is figyelembe veszszük a szerpreferenciák vizsgálatakor, akkor csak a marihuána/hasis marad bent a három legnépszerübb szer között, az ecstasyt és az amfetamint 95\%-os biztonsággal kiszorítja a szintetikus kannabisz (LTP: 11,2; hiba: $\pm 3,2$ ) és kétharmados biztonsággal az új stimulánsok (LTP: 9,6; hiba: $\pm 3,0)^{20}$ is megelözik ${ }^{21}$.

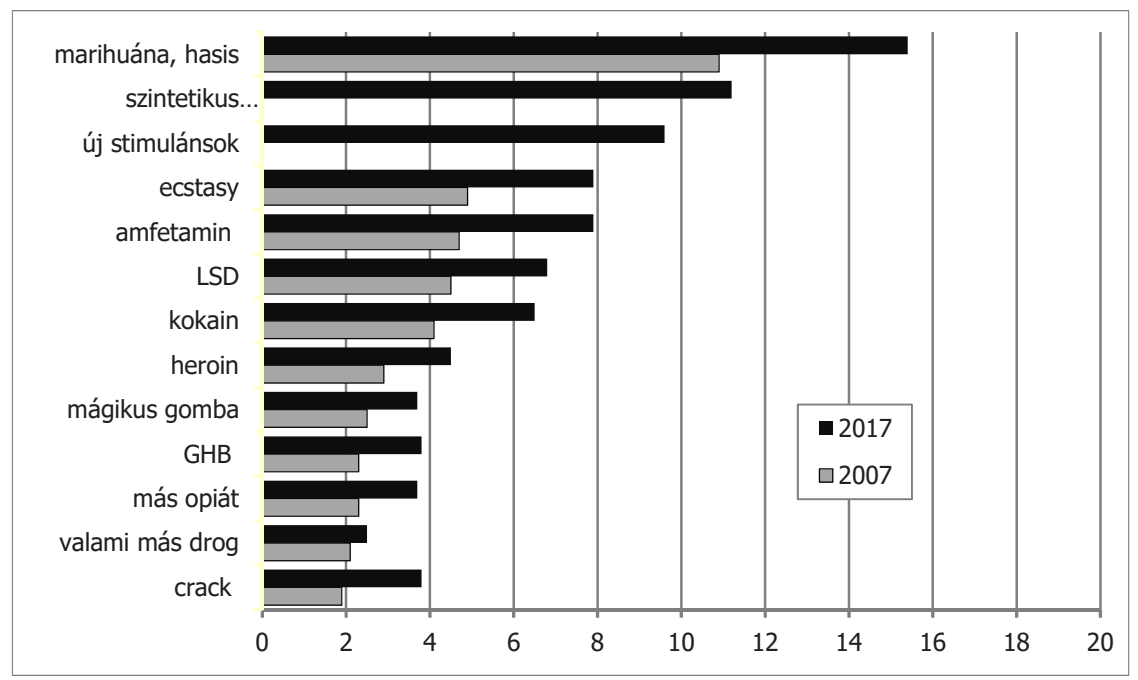

6. ábra Szerenkénti életprevalencia értékek a budapesti ellátásban részesülő hajléktalan populációban 2007-ben és 2017-ben (a válaszolók \%-ában)

Forrás: Paksi et al. (2010); F3DE 2017 kutatás

A fővárosi ellátásban részesülő hajléktalan populációban a hagyományos szerek struktúrájának stabilitása a hagyományos szerekre épített droghasználati piramis meredekségében, azaz a kannabiszhasználók egyéb szerpreferenciájának állandóságában is megjelenik (7. ábra). A valaha marihuánát/hasist használó ellátásban lévő fővárosi hajléktalanok körében korábban is, és 2017-ben is a legnépszerűbb szerek az ecstasy és az amfetamin, majd ezeket követi a kokain, az LSD, valamint a heroin. Mindössze a heroin esetében becsülhetjük azt, hogy kétharmados biztonsággal növekedett a népszerüsége a kannabiszt használók körében (2007 LTP: 22,2 hiba: \pm 10,2; 2017 LTP: 33,3 hiba: $\pm 11,6$; )

\footnotetext{
${ }^{19}$ A 2007-es szersorrend utolsó helyén lévő crack kivételével, ami a 2017-es vizsgálatban kétharmados biztonsággal egy hellyel elörébb került.

${ }^{20}$ Az ecstasy és az amfetamin LTP hibája 2007-ben $\pm 1,9$.

${ }^{21}$ A „más drogok” 2007-ben alacsony életprevalencia értéke megerősíti, hogy az új pszichoaktív szerek valóban a két vizsgálat között eltelt 10 évben kaptak meghatározó szerepet a szerstruktúrában.
} 


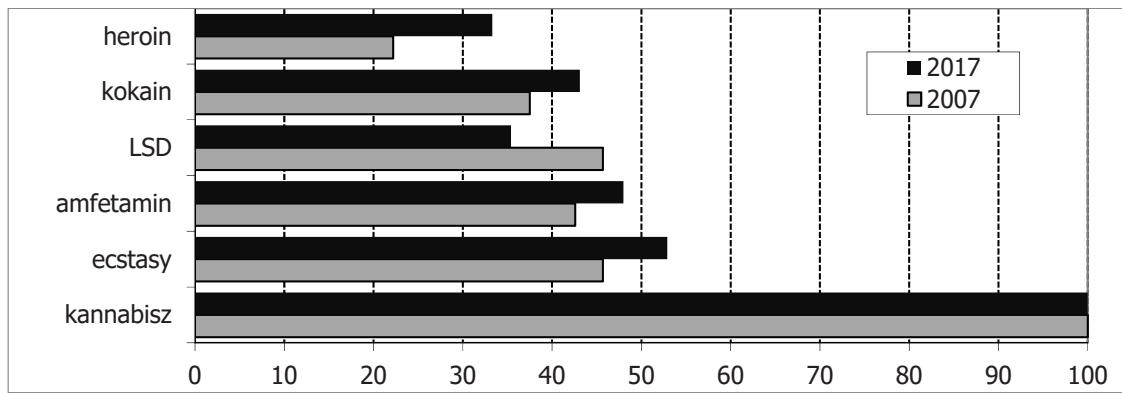

7. ábra Droghasználati piramis a budapesti ellátásban részesülő hajléktalan populációban 2007-ben és 2017-ben (a kannabiszt valaha használók \%-ában)

Forrás: Paksi et al. (2010); F3DE 2017 kutatás

A tendenciákat vizsgálva összességében tehát kétharmados biztonsággal azt mondhatjuk, hogy a fövárosi ellááásban részesülő hajléktalanok körében 2007 és 2017 között növekedett azok aránya, akik az életük során kipróbáltak valamilyen tiltott drogot. Szintén kétharmados biztonsággal növekedtek a mindkét időpontban vizsgált szerek életprevalencia értékei is. A fövárosi ellátásban lévő hajléktalan populáció szerhasználatának kockázatos jellegére utaló mintázódások nem változtak: a mindkét kutatásban vizsgált (hagyományos) drogok struktúrája, illetve droghasználati piramis meredeksége nem változott számottevően.

\subsubsection{Egyéb pszichoaktív szerek fogyasztásának változása a hajléktalan populációban}

A 2007-es és a 2017-es kutatás egyéb szerhasználattal kapcsolatos eredményei alapján 95\%-os megbízhatósági szinten azt mondhatjuk, hogy a fővárosi ellátásban részesülő hajléktalan populációban a vizsgált periódusban az alkoholfogyasztás szinte minden vizsgált mutatója javult: csökkent a fogyasztás elterjedtsége (TYP, LMP) és a nagy intenzitású, excesszív ivási magatartások (napi ivás, berúgás, binging) előfordulási gyakorisága is (12. táblázat). A dohányzás elterjedtsége és intenzitása tekintetében pedig a kutatás eredményei szerint nem tapasztalható elmozdulás.

12. táblázat Az alkoholfogyasztás és dohányzás összefoglaló mutatói a budapesti ellátásban részesülő hajléktalan populációban 2007-ben és 2017-ben (a kérdésre válaszolók százalékában)

\begin{tabular}{|l|c|c|c|c|c|c|}
\hline \multirow{2}{*}{ Mutatók } & \multicolumn{3}{|c|}{2007} & \multicolumn{3}{c|}{2017} \\
\cline { 2 - 7 } & $\mathrm{N}$ & $\%$ & hiba & $\mathrm{N}$ & $\%$ & hiba \\
\hline Az elmúlt évben ivott & 566 & 86,4 & $\pm 2,6$ & 391 & $\mathbf{7 0 , 8}$ & $\pm 4,1$ \\
\hline Az elmúlt hónapban ivott & 562 & 70,1 & $\pm 3,4$ & 385 & $\mathbf{5 3 , 2}$ & $\pm 4,6$ \\
\hline $\begin{array}{l}\text { Az elmúlt hónapban minden nap, } \\
\text { vagy majdnem minden nap ivott }\end{array}$ & 562 & 23,8 & $\pm 3,2$ & 383 & $\mathbf{1 5 , 7}$ & $\pm 3,4$ \\
\hline Az elmúlt évben volt részeg & 510 & 56,1 & $\pm 3,9$ & 376 & $\mathbf{4 3 , 6}$ & $\pm 4,6$ \\
\hline
\end{tabular}




\begin{tabular}{|l|c|c|c|c|c|c|}
\hline \multirow{2}{*}{ Mutatók } & \multicolumn{3}{|c|}{2007} & \multicolumn{3}{c|}{2017} \\
\cline { 2 - 7 } & $\mathrm{N}$ & $\%$ & hiba & $\mathrm{N}$ & $\%$ & hiba \\
\hline Elmúlt hónapban volt részeg & 429 & 32,6 & $\pm 4,1$ & 348 & $\mathbf{2 3 , 0}$ & $\pm 4,1$ \\
\hline $\begin{array}{l}\text { Elmúlt hónapban legalább } \\
3 \text { alkalommal volt részeg }\end{array}$ & 429 & 14,0 & $\pm 3,0$ & 335 & 14,3 & $\pm 3,5$ \\
\hline $\begin{array}{l}\text { Rohamivás* elöfordulása az elmúlt } \\
\text { évben }\end{array}$ & 560 & 65,5 & $\pm 3,6$ & 388 & $\mathbf{4 7 , 2}$ & $\pm 4,6$ \\
\hline Dohányzik & 561 & 81,3 & $\pm 2,9$ & 391 & 80,1 & $\pm 3,6$ \\
\hline $\begin{array}{l}\text { Napi cigarettamennyiség } \\
\text { (szál; átlag/módusz) }\end{array}$ & 413 & $22 / 20$ & & 270 & $17 / 20$ & \\
\hline *6 vagy több ital elfogyasztása egy alkalommal; N: Elemszám & & & \\
\hline A hibahatáron túli változásokat a táblázatban kiemeltük \\
\hline
\end{tabular}

Forrás: Paksi et al. (2010); F3DE 2017 kutatás

\section{A HAJLÉKTALAN POPULÁCIÓ PSZICHOAKTÍV SZERHASZNÁLATI SZOKÁSAIBAN MEGJELENÖ SAJÁTOSSÁGOK - AZ ÁLTALÁNOS POPULÁCIÓS ADATOK KONTEXTUSÁBAN}

A hajléktalan populáció drogérintettségét, fogyasztási szokásait a 2015-ben készült Országos Lakossági Adatfelvétel Addiktológiai Problémákról (OLAAP 2015) kutatás (Paksi et al. 2017) eredményeinek (Paksi - Demetrovics - Magi - Felvinczi 2018) kontextusában értelmezzük. Az általános populációs összehasonlítás során felhasznált adatok a magyarországi 18-64 éves lakosságot reprezentálják. Tekintettel arra, hogy a hajléktalan kutatás mintája a teljes (F3 kutatással elért) hajléktalan populációt reprezentálja életkori megkötés nélkül (a legfiatalabb megkérdezett 18 éves, a legidősebb 82 éves), ezért az összehasonlítás során a hajléktalan kutatás mintájából csak a 18-64 éves kor közöttiek szelektált, 1122 fös mintáját használjuk²2.

\subsubsection{A droghasználat elterjedtsége a hajléktalan és az általános népesség körében}

A 18-64 éves hajléktalanok országos mintáján mért prevalencia értékek rendre többszörösen meghaladják az általános népesség országos reprezentatív mintáján mért prevalencia értékeket. A rövidebb idejü prevalencia értékek felé haladva egyre intenzívebbé válik a különbség: míg az életprevalencia érték az általános népességhez viszonyítva „csak” két és félszer nagyobb a hajléktalanok körében, az éves prevalencia érték esetében már hat és félszeres, a havi prevalencia értékeknél pedig már nyolcszoros különbség tapasztalható (8. ábra).

\footnotetext{
${ }^{22}$ A hajléktalan mintában érvényesített életkori szelekció miatt az ebben a részben feltüntetett értékek esetenként kismértékben eltérhetnek a teljes mintára vonatkozó adatokat tartalmazó, előző részekben bemutatott adatoktól.
} 


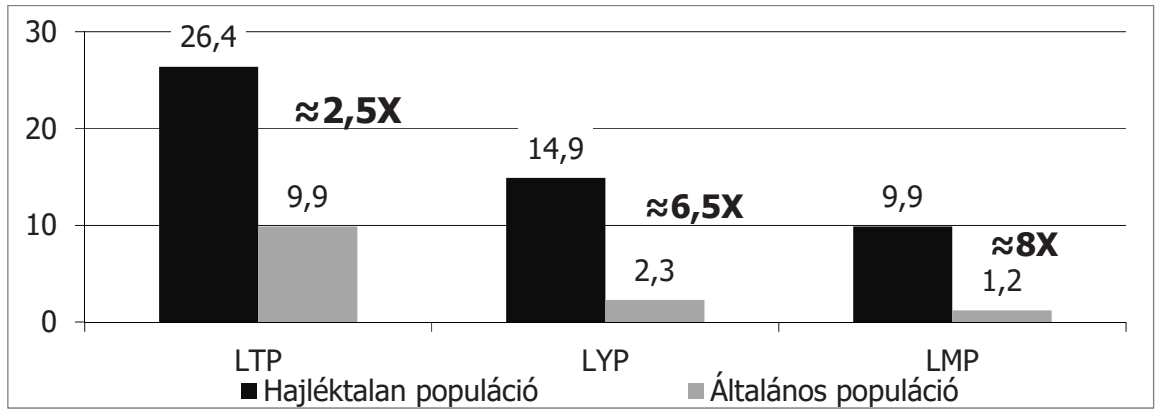

8. ábra A tiltott drogfogyasztás elterjedtsége a hajléktalan populációban és az általános népesség körében (a kérdésre válaszolók 18-64 évesek százalékában)

Forrás: Paksi et al. (2018); F3DE 2017 kutatás

A hajléktalan populáció tiltott drogfogyasztásának különböző időszakokra vonatkozó prevalencia értékeiben - az általános népességhez képest - megjelenő különbségeknek a rövidebb időszakra vonatkozó prevalencia értékek felé növekvő tendenciája azt is előrevetíti, hogy a valaha valamilyen tiltott drogot fogyasztó hajléktalanok körében inkább jellemző a drogok folyamatos használata. A valamilyen drogot valaha kipróbáló 18-64 éves hajléktalanok kétötöde az elmúlt évben is használt tiltott szert, míg az általános népességben a folyamatos használók aránya „csak” 17,6\%, a kilépési arány pedig a hajléktalan populációban fele a droghasználók körében általában jellemző aránynak (13. táblázat). A folyamatos használat mutatói tehát azt jelzik, hogy a hajléktalan populáció drogfogyasztása egy olyan, fokozottan kockázatos szerhasználat, amiből nagyon nehéz a kilépés, a felépülés. További fontos sajátossága a hajléktalan népesség droghasználatának a droghasználatot a közelmúltban (a kutatást megelőző 12 hónapban) elkezdők (ún. új belépők) magas aránya: az új belépők aránya a hajléktalan populációban több mint háromszorosa az általános populációban mért értéknek, ami a magas közelmúltbeli használat egy további fontos összetevője.

13. táblázat $A$ folyamatos droghasználat a hajléktalan populációban és az általános népesség körében (a valaha valamilyen tiltott drogot fogyasztó 18-64 évesek százalékában)

\begin{tabular}{|l|c|c|}
\hline & Hajléktalan populáció & Általános populáció \\
\hline Folyamatos fogyasztási ráta & $\mathbf{4 0 , 2}$ & $\mathbf{1 7 , 6}$ \\
\hline Kilépők aránya & $\mathbf{3 8 , 4}$ & $\mathbf{7 6}$ \\
\hline Új belépők & $\mathbf{2 1 , 4}$ & 6,4 \\
\hline
\end{tabular}

Forrás: Paksi et al. (2018); F3DE 2017 kutatás

A hajléktalan populáció szerhasználati prioritásai (9. ábra) bizonyos szempontból leképezik a lakosság szerhasználati preferenciáit. A legelterjedtebb drogok mindkét populációban a marihuána, a partidrogok, valamint az új pszichoaktív szerek. A hagyományos tiltott drogok tekintetében a szerek sorrendje is megegyezik az általános népességben jellemző szerpreferen- 
ciákkal: a legnépszerübb hagyományos tiltott szer mindkét populációban a marihuána, ezt követi az ecstasy és az amfetamin.

Ugyanakkor fontos különbségekre is fel kell hívnunk a figyelmet. Az egyik ilyen eltérés az új pszichoaktív szerek szerepe. Ugyan a 2015-ös lakossági vizsgálat adatai - a droghasználat közvetett indikátoraival összhangban - azt mutatták, hogy az új pszichoaktív szerek használata meghatározóvá vált a hazai tiltottdrog-használatban (Paksi 2017), az új szerek a hajléktalan populáció szerstruktúrájában sokkal inkább szerepet kapnak: míg a lakosság szerstruktúrájában a szintetikus kannabisz a harmadik legelterjedtebb szer volt 2015-ben, az új stimulánsok pedig az ötödik helyen voltak, a hajléktalan populációban a kannabisz után a legnépszerübb drog a szintetikus kannabisz, és az új stimulánsok, az ecstasy, valamint az amfetamin hibahatáron belül megegyező életprevalencia értékekkel holtversenyben a harmadik helyen szerepelnek. Míg a kannabisz életprevalencia értéke a hajléktalan populációban két és félszerese a normálpopulációs értéknek, és általában az egyéb drogoké pedig háromszorosa, addig az új pszichoaktív szerek elterjedtsége 7-7,5-ször nagyobb.

A hajléktalan populációban és az általános népességben mért szerenkénti prevalencia értékek összehasonlításának másik fontos tapasztalata, hogy míg a tiltott drogok összesített életprevalencia értéke mintegy 2,5-szöröse az általános népességben mért értékeknek (lásd a 8. ábrán), addig a szerenkénti értékek - a kannabisz és az ecstasy kivételével - legalább háromszor, a vizsgált szerek több mint fele esetében pedig több mint ötször nagyobbak.

Itt jegyezzük meg továbbá, hogy az intravénás szerhasználat is jelentősen nagyobb szerephez jut a hajléktalanok szerhasználatában. A hajléktalanok 5,5\%-a használt már valamilyen drogot intravénásan (LYP: 2,9\%, LMP: 1,9\%), míg az általános populációban az intravénás droghasználat életprevalencia értéke mindössze $0,4 \%$.

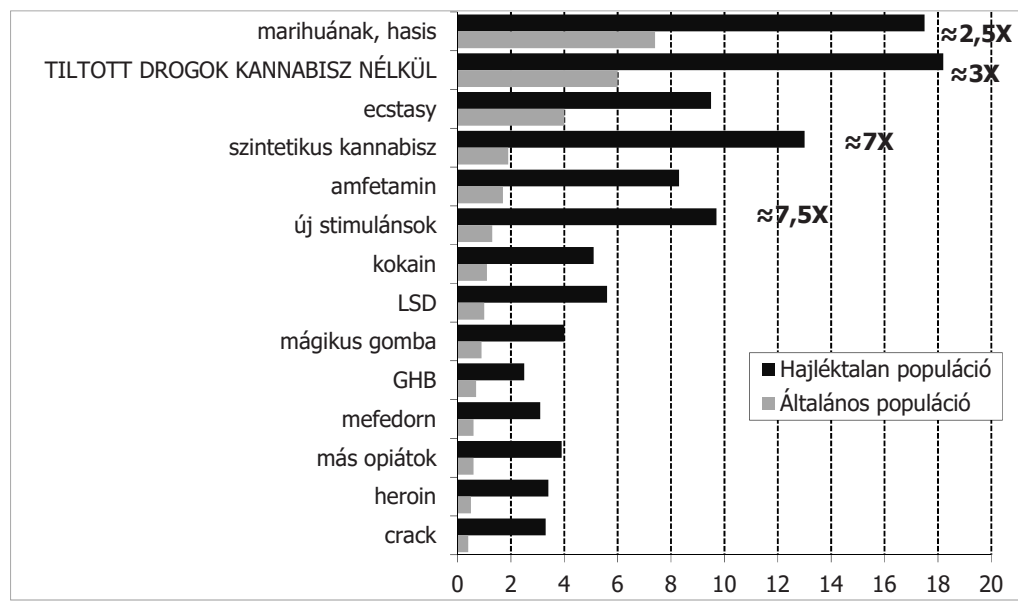

9. ábra Szerenkénti életprevalencia értékek a hajléktalan populációban és az általános népesség körében (a kérdésre válaszolók 18-64 évesek százalékában)

Forrás: Paksi et al. (2018); F3DE 2017 kutatás 


\subsubsection{A szintetikus kannabiszra épitett droghasználati piramis a hajléktalan és az általános népesség körében}

Mint ahogy a tanulmány előző, a szerenkénti prevalencia értékkel foglalkozó részében láttuk, az új pszichoaktív szerek a hajléktalan populáció szerstruktúrájában a lakossághoz képest sokkal inkább meghatározó szerepet kapnak.

A lakossági vizsgálat adatai alapján végzett korábbi elemzések ugyanakkor azt jelezték, hogy az ÚPSZ-használat nem egy speciális, más szerhasználó magatartásoktól elkülönülő fogyasztói magatartás, az általános népességben az ÚPSZ-használók nem képeznek egy új szerhasználói csoportot. Ennek egyik indikátoraként az általános népességben a szintetikus kannabisz fogyasztásra épített piramis azt jelezte, hogy „....a szintetikus kannabiszt használók körében több mint harmincszor nagyobb az esélye a heroin, illetve az új stimulánsok kipróbálásának, 22-27-szeres az LSD-, illetve az amfetaminhasználat előfordulásának, tízszeres a valószínűsége annak, hogy fogyasztottak már kannabiszt, vagy ecstasyt, mint általában a felnőtt népességben" (Paksi 2017: 56).

Amennyiben az általános népesség szintetikus kannabisz fogyasztásra épített droghasználati piramisát összevetjük a hajléktalan populációban épített piramissal (10. ábra), a két piramis nagyfokú hasonlósága mellett azt is láthatjuk, hogy a hajléktalan populációban még inkább összekapcsolódik a szintetikus kannabisz fogyasztása más tiltott drogok fogyasztásával, azonban míg az általános népesség esetén nem kapott kitüntetett szerepet a két új pszichoaktív szer kapcsolódása, a hajléktalan populációban ez nagyon erősen megjelenik. A szerhasználati piramisban szokásosan szereplő szereket kiegészítve az intravénás szerhasználatra vonatkozó adatokkal, egy további markáns eltérés mutatkozik meg: a szintetikus kannabiszt fogyasztó hajléktalan emberek esetében az intravénás beviteli mód több mint két és félszer gyakoribb, mint az általános népességben szintetikus kannabiszt használók körében.

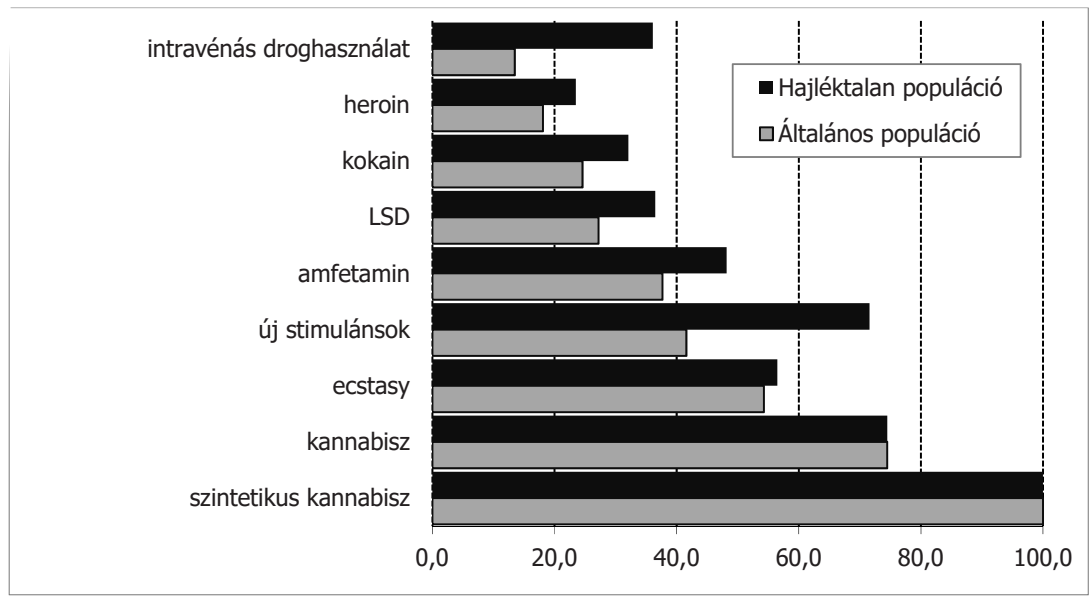

10. ábra A szintetikus kannabisz használatra épített droghasználati piramis a hajléktalan populációban és az általános népességben (18-64 éves szintetikus kannabisz használók százalékában)

Forrás: Paksi et al. (2018); F3DE 2017 kutatás 


\subsubsection{Polydrog-használat a hajléktalanok és az általános népesség körében}

A hajléktalan populációban és az általános népességben mért szerenkénti prevalencia értékek összehasonlítása során azt is láthattuk, hogy míg a tiltott drogok összesített életprevalencia értéke mintegy 2,5-szöröse az általános népességben mért értékeknek, addig a szerenkénti értékek - a kannabisz és az ecstasy kivételével - legalább háromszor, a vizsgált szerek több mint fele esetében pedig több mint ötször nagyobbak. Az, hogy a két populáció között az összesített életprevalencia értékhez képest a szerenkénti életprevalencia értékek esetében nagyobb különbségek mutatkoztak, előrevetíti a hajléktalan droghasználóknak a polydroghasználatban való fokozott érintettségét. Ez a fokozott érintettség különösen a három- vagy többféle szert fogyasztók arányának markáns különbségében mutatkozik meg: míg az általános népességben a droghasználók mintegy egyharmada, addig a hajléktalan populáció több mint fele használt a közelmúltban három vagy több, egyharmaduk legalább négyféle drogot (11. ábra).

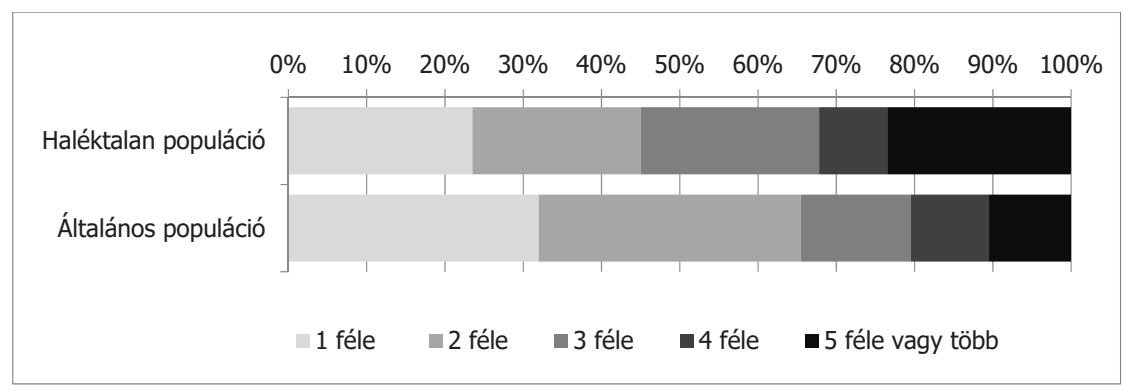

11. ábra Polydrog-használat a hajléktalan populációban és az általános népességben (18-64 éves közelmúltbeli droghasználók [LYP] százalékában)

Forrás: Paksi et al. (2018); F3DE 2017 kutatás

\subsubsection{Egyéb pszichoaktiv szerhasználat a hajléktalanok és az általános népesség körében}

A hajléktalan populáció fokozott pszichoaktív szerhasználata nem csak a tiltott drogok vonatkozásában figyelhető meg. Kutatásunk alkoholfogyasztási és dohányzási adatait általános populációs kontextusba helyezve a hajléktalan populáció e tekintetben is fokozott kitettségét jelezte (14. táblázat). A hajléktalan populációban több mint kétszer nagyobb a dohányosok aránya, mint a lakosságban, bár a dohányzás intenzitása az átlagpopulációéhoz hasonló. Alkoholfogyasztás tekintetében pedig minden mutató, különösen is a nagy intenzitású, excesszív ivási magatartások (napi ivás, berúgás, binging) tekintetében mutatkozik az általános népességhez képest fokozott kockázat a hajléktalan populációban. 
14. táblázat Az egyéb pszichoaktív szerhasználat elterjedtségére vonatkozó összefoglaló mutatók a hajléktalan populációban és az általános népesség körében

(a kérdésre válaszoló 18-64 évesek százalékában)

\begin{tabular}{|l|c|c|c|c|c|c|}
\hline & $\mathrm{N}$ & $\begin{array}{c}\text { Hajléktalan } \\
\text { populáció }\end{array}$ & $\begin{array}{c}\text { Standard } \\
\text { hiba }\end{array}$ & $\mathrm{N}$ & $\begin{array}{c}\text { Általános } \\
\text { népesség }\end{array}$ & $\begin{array}{c}\text { Standard } \\
\text { hiba }\end{array}$ \\
\hline Az elmúlt évben ivott & 1090 & $\mathbf{8 0 , 5}$ & $\pm 2,2$ & 1427 & 74,2 & $\pm 2,3$ \\
\hline Az elmúlt hónapban ivott & 1083 & $\mathbf{6 6 , 5}$ & $\pm 2,6$ & 1427 & 51,3 & $\pm 2,6$ \\
\hline $\begin{array}{l}\text { Az elmúlt hónapban minden } \\
\text { nap, vagy majdnem minden } \\
\text { nap ivott }\end{array}$ & 1080 & $\mathbf{2 7 , 4}$ & $\pm 2,4$ & 1427 & 5,4 & $\pm 1,2$ \\
\hline Az elmúlt évben volt részeg & 1058 & $\mathbf{6 0 , 4}$ & $\pm 2,7$ & 1373 & 21,0 & $\pm 2,1$ \\
\hline $\begin{array}{l}\text { Rohamivás* elöfordulása az } \\
\text { elmúlt évben }\end{array}$ & 1079 & $\mathbf{6 0 , 7}$ & $\pm 2,7$ & 1409 & 21,4 & $\pm 2,1$ \\
\hline Dohányzik & 1086 & $\mathbf{8 4}$ & $\pm 2,0$ & 1486 & 35,9 & $\pm 2,4$ \\
\hline $\begin{array}{l}\text { Napi cigarettamennyiség } \\
\text { (szál; átlag/módusz) }\end{array}$ & 775 & $16,7 / 20$ & & 530 & $15 / 20$ & \\
\hline $\begin{array}{l}\text { A hibahatárnál nagyobb eltérések esetén a magasabb értékeket a táblázatban kiemeltük. } \\
\text { *6 vagy több ital elfogyasztása egy alkalommal }\end{array}$ & \\
\hline
\end{tabular}

Forrás: Paksi et al. (2018); F3DE 2017 kutatás

\section{6. ÖSSZEGZÉS}

A tanulmányban bemutatott, a hajléktalan populáció országos reprezentatív mintáján 2017 ben készült kutatás eredményei alapján Magyarországon a hajléktalan emberek egynegyede használt már életében valamilyen tiltott drogot. Az elmúlt évben megközelítőleg minden hetedik, az elmúlt hónapban pedig közel minden tizedik fogyasztott valamilyen tiltott szert.

A hajléktalan populációban az életprevalencia értékek alapján a legelterjedtebb tiltott drog a marihuána/hasis: minden ötödik-hatodik válaszoló fogyasztott már életében marihuánát vagy hasist. Ezzel azonos nagyságú azonban az a populáció, aki a kannabisz származékokon kívül használt már egyéb tiltott drogokat is. A népszerüségi sorrendben a kannabiszt a szintetikus kannabisz, majd azonos aránnyal az új stimulánsok, az ecstasy és az amfetamin származékok követik. A hajléktalan populáció közelmúltbeli droghasználatban pedig már az egyéb tiltott drogok a meghatározóbbak, és az új pszichoaktív szerek különösen dominánssá válnak.

A különböző tiltott drogok használata erős kapcsolódást mutat a hajléktalan populációban: kevesebb mint egynegyedre tehető azok aránya, akik mindössze egyféle droggal próbálkoztak. A droghasználó hajléktalanok több mint háromnegyede polydrog-használónak tekinthető, s tízből öten-hatan legalább háromféle, közel egynegyedük pedig öt- vagy többféle tiltott drogot próbált már ki.

Azoknak a hajléktalanoknak, akik használtak már az életük során valamilyen drogot, egyharmadának az éltében volt olyan időszak, amikor a drogfogyasztás miatt fizikai és/vagy lelki 
problémái jelentkeztek, illetve személyes és/vagy intézményes kapcsolataiban megmutatkoztak a drogfogyasztás következményes károsodásai. A droghasználó hajléktalanok droghasználattal kapcsolatos kezelési igényét jelzi, hogy tízből közel három (a populációra vetítve 7,7\%-os arányt jelent) megjelent az élete során járó- vagy fekvőbeteg egészségügyi ellátásban a droghasználatával összefüggésben.

A hajléktalan populációban a droghasználat előfordulásának társadalmi mintázódását vizsgálva a férfiak, a fiatal felnőttek, a hajléktalan-ellátásban nem részesülők (utcán élők), továbbá a környezetük által romának tekintett hajléktalanok fokozott kockázatát kell kiemelnünk. Az ellátásban lévő és az utcán élő hajléktalanok között vidéken és a fővárosban is szignifikáns különbség tapasztalható, s a leginkább érintett a fövárosban utcán elért populáció, ahol a válaszolók mintegy kétötöde fogyasztott már életében, és közel egyharmada az elmúlt hónapban is valamilyen tiltott drogot.

Kutatásunk választ keresett a klasszikus „tyúk vagy tojás” kérdésre is, azaz arra, hogy a droghasználó hajléktalanok esetében a hajléktalanná válás előzte-e meg a droghasználatot, vagy a droghasználat a hajléktalanná válást. A kutatás eredményei azt mutatják, hogy a droghasználó hajléktalanok többsége a hajléktalanná válását megelőzően használt már valamilyen tiltott drogot, és elenyésző azok aránya, akik esetében az első droghasználat a hajléktalanná válást követően történt. Természetesen az összefüggés vizsgálata csak a két helyzet időbelisége, s nem az ok-okozati relációja vonatkozásában szolgál információval.

Összességében - az adatokat időbeni és általános populációs kontextusba helyezve - kétharmados biztonsággal azt mondhatjuk, hogy a fóvárosi ellátásban részesülő hajléktalanok körében 2007 és 2017 között növekedett azok aránya, akik az életük során kipróbáltak valamilyen tiltott drogot. A fövárosi ellátásban lévő hajléktalan populáció szerhasználatának kockázatos jellegére utaló mintázódások azonban nem változtak. Míg 2007-ben azt mondhattuk, hogy a drogokkal való kapcsolatba kerülés tekintetében a fóvárosi hajléktalan emberek kitettsége átlagosnak mondható, a problémás/kockázatos droghasználat tekintetében azonban különösen veszélyeztetettek, 2017-ben Magyarországon a hajléktalan emberek droghasználati kitettsége többszöröse az általános népességben tapasztalhatónak, s a fogyasztásuk fokozottan kockázatos jellege sem csökkent.

A hajléktalan emberek fokozott pszichoaktív szerhasználata nem csak a tiltott drogok vonatkozásában figyelhető meg. Ugyan az egyéb pszichoaktív szerhasználat tekintetében nem tapasztalhatók kedvezőtlen tendenciák, azonban a hajléktalan populációban mind a dohányzás, mind az alkoholfogyasztás mutatói jóval kedvezőtlenebbek, mint általában a lakosságban. 


\section{IRODALOM}

Bényei Z. - Gurály Z. - Győri P. - Mezei Gy. (2000): Tíz év után. Gyorsjelentés a fővárosi hajléktalanokról - 1999. Esély, 1: 62-95.

Bill E. - Henk M. (2006): Fifth review of statistics on Homelessness in Europe, FEANTSA. https:// www.feantsaresearch.org/download/5-2006449618011929240409.pdf (Utolsó letöltés: 2020.01.10.)

Dávid B. - Snijders T. (2000): A Budapesti hajléktalanok számának becslése. Szociológiai Szemle, 10(3): 60-75.

Elekes Zs. - Paksi B. (2003): A 18-54 éves felnőttek alkohol- és egyéb drogfogyasztási szokásai. Kutatási Beszámoló. Budapest: NKFP. http://viselkedeskutato.hu/index.php?option=com_ attachments\&task=download\&id=57\&lang=hu (Utolsó letöltés: 2020.01.10.)

EMCDDA (1999): Co-ordination of an expert working group to develop instruments and guidelines to improve quality and comparability of general population surveys on drugs in the EU. Follow up of EMCDDA project CT.96.EP.08 (CT.97.EP.09), Lisbon: EMCDDA, September 1999. http://www.emcdda.europa.eu/system/files/publications/244/downloads lemcdda_gps_expert_group_comp_report.pdf (Utolsó letöltés: 2020.01.10.)

EMCDDA (2002): Handbook for surveys on drug use among the general population. EMCDDA project CT.99.EP.08 B, Lisbon: EMCDDA, August 2002. http://www.emcdda.europa.eu/ system/files/publications/244/Handbook_for_surveys_on_drug_use_among_the_ general_population_-_2002_106510.pdf (Utolsó letöltés: 2020.01.10.)

EMCDDA (2015): Voluntary EMQ Module for monitoring use of New (and not so new) Psychoactive Substances (NPS) in General Adult Population Surveys and School Surveys. Lisbon: EMCDDA. http://www.emcdda.europa.eu/attachements.cfm/att_249891_EN_ EMQ\%20Voluntary\%20Module\%20on\%20New\%20Psychoactive\%20Substances\%20 (NPS).pdf (Utolsó letöltés: 2020.01.10.)

Paksi B. (2003): Drogok és felnőttek. A tizennyolc év feletti lakosság drogfogyasztása és droggal kapcsolatos gondolkodása az ezredfordulón, Magyarországon. Szakmai forrás sorozat. 4. Budapest: L'Harmattan.

Paksi B. (2017): ÚPSZ-használattal kapcsolatos epidemiológiai tapasztalatok az Országos Lakossági Adatfelvétel Addiktológiai Problémákról (OLAAP 2015) címü kutatás alapján. In: Felvinczi K. (szerk.): Változó Képletek - ÚJ(abb) szerek: kihívások, mintázatok, megoldások. Budapest: L'Harmattan, 45-68.

Paksi B. - Arnold P. (2009): Speciális populációk drogérintettsége. In: Demetrovics Zs. (szerk.): Az addiktológia alapjai II. Budapest: Eötvös Kiadó, 327-387.

Paksi B. - Rózsa S. - Kun B. - Arnold P. - Demetrovics Zs. (2009): A magyar népesség addiktológiai problémái: az Országos Lakossági Adatfelvétel az Addiktológiai Problémákról (OLAAP) reprezentatív felmérés módszertana és a minta leíró jellemzői. Mentálhigiéné és

Pszichoszomatika 10. 4, 273-300. http://real.mtak.hu/58254/1/mental.10.2009.4.1.pdf (Utolsó letöltés: 2020.01.10.) 
Paksi B. - Arnold P. - Schmidt A. - Gurály Z. - Breitner P. (2010): Drogfogyasztás és hajléktalanság. In: Győri P. - Vida J.: Otthontalanul... Tégy az emberért! Budapest: Menhely Alapítvány és BMSZKI, 49-76.

Paksi B. - Demetrovics Zs. - Magi A. - Felvinczi K. (2017): Az Országos Lakossági Adatfelvétel az Addiktológiai Problémákról 2015 (OLAAP 2015) reprezentatív lakossági felmérés módszertana és a minta leíró jellemzői. Neuropsychopharmacologia Hungarica, 19(2): 55-85. http://epa.oszk.hu/02400/02454/00066/pdf/EPA02454_neuropsychopharmacologia_ hungarica_2017_02_055-085.pdf (Utolsó letöltés: 2020.01.10.)

Paksi B. - Demetrovics Zs. - Magi A. - Felvinczi K. (2018): A magyarországi felnőtt népesség droghasználata - az Országos Lakossági Adatfelvétel az Addiktológiai Problémákról 2015 (OLAAP 2015) reprezentatív lakossági felmérés alapján. Magyar Pszichológiai Szemle, 73(4/2): 541-565. https://doi.org/10.1556/0016.2018.73.4.2

Paksi B. - Gurály Z. - Arnold P. - Schmidt A. - Breitner P. (2008): A drogfogyasztás és hajléktalanság. Addiktológia. 2: 101-130.

Paksi B. - Magi A. (2017): Hajléktalanság és droghasználat. A hajléktalan populáció drog-és egyéb pszichoaktív szerhasználatának vizsgálata. Kutatási beszámoló, Budapest: EMMI. 